\title{
A new methodological framework by geophysical sensors combinations associated with machine learning algorithms to understand soil attributes
}

Danilo César de Melloㄹ; Gustavo Vieira Velosoㄹ; Marcos Guedes de Lana ${ }^{1}$; Fellipe Alcantara de 5 Oliveira Mello ${ }^{2}$; Raul Roberto Poppiel ${ }^{2}$; Diego Ribeiro Oquendo Cabrero ${ }^{3}$; Luis Augusto Di Loreto Di Raimo ${ }^{4}$; Carlos Ernesto Gonçalves Reynaud Schaefer'; Elpídio Inácio Fernandes Filho'; Emilson Pereira Leite ${ }^{4}$; José Alexandre Melo Demattêt ${ }^{2 *}$

${ }^{1}$ Department of Soil Science, Federal University of Viçosa: daniloc.demello@gmail.com; gustavo.v.veloso@gmail.com; marcosguedeslana@gmail.com; carlos.schaefer@ufv.br; elpidio@ufv.br

$10 \quad{ }^{2}$ Department of Soil Science, "Luiz de Queiroz" College of Agriculture, University of São Paulo, Av. Pádua Dias, 11, CP 9, Piracicaba, SP 13418-900, Brazil; emails: fellipeamello@usp.br; raulpoppiel@gmail.com; luis.diloreto@hotmail.com; jamdemat@usp.br*

${ }^{3}$ Geography Department of Federal University of Mato Grosso do Sul, Av. Ranulpho Marques Leal, $\mathrm{n}^{\circ} 3484$ - Distrito Industrial CEP 79610-100 Três Lagoas/MS: diego.cabrero@gmail.com

$15{ }^{4}$ Department of Geology and Natural Resources, Institute of Geosciences, University of Campinas, Rua Carlos Gomes, 250, Cidade Universitária, CEP 13083-855, Campinas/SP: emilson@ige.unicamp.br

Correspondence to: José Alexandre Melo Demattê (jamdemat@usp.br)

Abstract. Geophysical sensors combined with machine learning algorithms have been used to understand the pedosphere system, landscape processes and to model soil attributes. In this research, we used parent material, terrain attributes and data

20 from geophysical sensors in different combinations, to test and compare different and novel machine learning algorithms to model soil attributes. Also, we analyzed the importance of pedoenvironmental variables in predictive models. For that, we collected soil physico-chemical and geophysical data (gamma-ray emission from uranium, thorium and potassium, magnetic susceptibility and apparent electric conductivity) by three sensors, gamma-ray spectrometer - RS 230, susceptibilimeter KT10 - Terraplus and Conductivimeter - EM38 Geonics) at 75 points and, we performed soil analysis afterwards. The results showed varying models with the best performance $\left(\mathrm{R}^{2}>0.2\right)$ for clay, sand, $\mathrm{Fe}_{2} \mathrm{O}_{3}, \mathrm{TiO}_{2}, \mathrm{SiO}_{2}$ and Cation Exchange Capacity prediction. Modeling with selection of covariates at three phases (variance close to zero, removal by correction and removal by importance), demonstrated to be adequate to increase the parsimony. The prediction of soil attributes by machine learning algorithms demonstrated adequate values for field collected data, without any sample preparation, for most of the tested predictors $\left(\mathrm{R}^{2}\right.$ ranging from 0.20 to 0.50$)$. Also, the use of four regression algorithms proved important, since at least one of the predictors used one of the tested algorithms. The performances of the best algorithms for each predictor were higher than the use of a mean value for the entire area comparing the values of Root Mean Square Error (RMSE) and Mean Absolute Error (MAE). The best combination of sensors that reached the best model performance to predict soil attributes were gamma-ray spectrometer and susceptibilimeter. The most important variables were parent material, digital elevation model, standardized height and magnetic susceptibility for most predictions. We concluded that soil attributes can be 
https://doi.org/10.5194/gmd-2021-153

Preprint. Discussion started: 16 July 2021

(c) Author(s) 2021. CC BY 4.0 License.

(c) (i)

35 efficiently modelled by geophysical data using machine learning techniques and geophysical sensors combinations. The technique can bring light for future soil mapping with gain of time and environment friendly.

\section{Introduction}

The pedosphere is composed by soils and their connections with hydrosphere, lithosphere, atmosphere and biosphere (Targulian et al, 2019). Soils are the result of several processes and factors and their interactions, which produces specific

40 soils types or horizons. The main soil processes are weathering and pedogenesis (Breemen and Buurman, 2003; Schaetzl and Anderson, 2005), while the soil-forming factors are parent material, relief, climate, organisms and time (Jenny, 1994). Their interactions during soil genesis results in different soil attributes such as texture, mineralogy, color, structure, base saturation, clay activity and others.

In the last decades, there is a growing demand for soil resource information worldwide (Amundson et al., 2015;

45 Montanarella et al., 2015). Soils are recognized as having a key influence on global issues such as, water availability, food security, sustainable energy, climate change and environmental degradation (Amundson et al., 2015; Pozza and Field, 2020). Understanding the role of spatial variations in surface and subsurface soil is fundamental for its sustainable use as well as other connected environmental resources and monitoring (Agbu et al., 1990). Therefore, it is necessary to increase the acquisition of information on the functional attributes of soils an ever-growing. To achieve this goal, relevant and reliable

50 soil information, applicable from local to global scales is required (Arrouays et al., 2014).

The acquisition of soils data and their attributes are traditionally achieved by traditional soil survey techniques. However, new geotechnologies have emerged in the last decades, allowing the acquisition of data at shorter times, with non-invasive and accurate methods, such as reflectance spectroscopy, satellite imagery and geophysical techniques (Mello et al., 2020; Demattê et al., 2017, 2007; Fioriob, 2013; Fongaro et al., 2018; Mello et al., 2021; Terra et al., 2018a, 2018b). Among these

55 technologies, geophysical sensors have been recently used in pedology to understand pedogenesis and the relationship between these processes and soil attributes (Son et al., 2010; Schuler et al., 2011; Beamish, 2013; McFadden and Scott, 2013; Sarmast et al., 2017; Reinhardt and Herrmann, 2019). Among these geophysical techniques used, we highlight the gamma-spectrometry, magnetic susceptibility $(\kappa)$ and apparent electrical conductivity $(\mathrm{ECa})$.

Gamma-ray spectrometry can be defined as the measurements of natural gamma radiation emission from natural emitters,

60 such as $\mathrm{K}^{40}$, the daughter radionuclides of $\mathrm{U}^{238}$ and $\mathrm{Th}^{232}$, and total emissions from all elements in soils, rocks and sediments (Minty, 1988). It is known that weathering and pedogenesis concomitantly with geochemical behavior of each radionuclide determine their distribution and concentration in the pedosphere (Dickson and Scott, 1997; Wilford and Minty, 2006; Mello et al., 2021). Therefore gamma-ray spectrometry can provide important information for comprehension of soil processes and attributes (Reinhardt and Herrmann, 2019), soil texture (Taylor et al., 2002a), mineralogy (Wilford and Minty 2006;

65 Barbuena et al. 2013), pH (Wong and Harper, 1999) and organic carbon (Priori et al., 2016) and others. 
https://doi.org/10.5194/gmd-2021-153

Preprint. Discussion started: 16 July 2021

(c) Author(s) 2021. CC BY 4.0 License.

Soil magnetic susceptibility (к) can be defined as the degree to which soil particles can be magnetized (Rochette et al., 1992). The $\kappa$ is related to several pedoenvironmental factors, such as soil mineralogy, lithology and geochemistry of ferrimagnetic secondary minerals, mainly magnetite and maghemite (Ayoubi et al., 2018). Also, the $\kappa$ parameter can be related to other soil secondary minerals, like ferrihydrite and hematite (Valaee et al., 2016). The great potential of this technique is related to geological studies (Shenggao 2000; Correia et al. 2010), soil texture and organic carbon studies (Camargo et al., 2014; Jiménez et al., 2017), soil survey (Grimley et al., 2004) and pedogenesis e pedogeomorphological processes (Viana et al., 2006; Sarmast et al., 2017; Mello et al., 2020).

Apparent electrical conductivity (ECa) is the ability of the soil to conduct electrical current, expressed in millisiemens per metre. This soil property is related to the presence/amount of solutes in soil solution, which concentration in $1 \mathrm{dS} / \mathrm{m}$ is equivalent to $10 \mathrm{meq} / \mathrm{L}$ (Richards, 1954). Concerning the geophysical methods consideration, the ECa is a geotechnology for identifying the soil physicochemical attributes and its spatial variation (Corwin et al., 2003). Many different soil attributes are related to the ECa such as soil salinity (Narjary et al., 2019), soil texture (Domsch and Giebel, 2004), cation exchange capacity (Triantafilis et al., 2009), mineralogy, pore size and distribution, temperature, soil moisture (McNeill, 1992; Rhoades et al., 1999; Bai et al., 2013; Farzamian et al., 2015; Cardoso and Dias, 2017).

80 Many sensors scan only the soil surface, disregarding the entire soil tridimensional profile (Xu et al., 2019). Therefore, a single sensor may not be able or be the best solution to quantify multiple soil attributes. In this context, the concept and use of multi-sensor data acquisition and analysis in a complementary way to offer more robust and accurate estimations of a number of soil attributes (Xu et al., 2019; Javadi et al., 2021). The analysis of soil data acquired by multiple sensors requires a careful interpretation and a mathematical model, which can be considered the base of observed variation and provides the

85 basis for generalization, prediction and interpretation. (Heuvelink and Webster, 2001).

Recently, many models have been used to estimate soil attributes and their spatial distribution from geophysical data (gamma-ray, $\kappa$ and ECa) and soil attributes, including machine learning algorithms, such as Support Vector Machine-SVM (Priori et al., 2014; Heggemann et al., 2017; Li et al., 2017; Leng et al., 2018; Zare et al., 2020), Random Forests (Lacoste et al., 2011; Viscarra Rossel et al., 2014; Harris and Grunsky, 2015; Sousa et al., 2020), KNN and artificial neural network

90 (ANN) (Ã and Onjia, 2007) and Cubist (Wilford and Thomas, 2012).

According to Batty and Torrens, (2001), the bests models are those capable of explaining the same phenomena using the smallest number of variables without loss of performance, following the principle of parsimony - Occam's razor. This facilitates the understanding and the faster computer processing (Brungard et al., 2015). In this context, the Recursive Feature Elimination (RFE) algorithm may be used for backward selection of optimal subsets of variables, while maintaining

95 a satisfactory model performance (Vašát et al., 2017; Hounkpatin et al., 2018).

Some of geophysical sensors are able to detect soil attributes in the upper soil layers (0- $0.50 \mathrm{~m}$ for gamma-ray by the RS230 model, $0.02 \mathrm{~m}$ for magnetic susceptilimeter KT10 Terraplus model and $1.5 \mathrm{~m}$ for conductivimeter by EM38 model, for example), which are explained by naturally occurring soil processes and soil factor forming (Mello et al., 2020; Mello et al., 2021). However, there is still a gap regarding the identification of the bests covariables and their possible combinations to 
https://doi.org/10.5194/gmd-2021-153

Preprint. Discussion started: 16 July 2021

(c) Author(s) 2021. CC BY 4.0 License.

(c) (i)

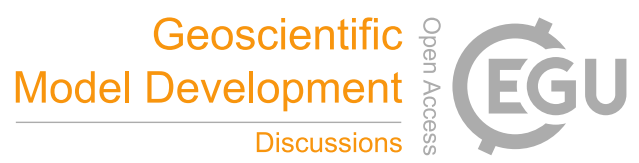

100 deepen the knowledge of the soil weathering, genesis and their relation to soil attributes. A standard approach to selecting the bests input data to soil prediction models has yet to be developed (Levi and Rasmussen, 2014), mainly for geophysical sensors, little few used in soil science. The identification of such covariates may improve the understanding of the soil processes and attributes interplays, allowing an enhanced comprehension of soils from punctual to landscape scale, supporting digital soil mapping and better soil use and management.

105 Given this, the research aimed to: $i$ ) develop a new methodological framework on modelling soil attributes using combined data from three different geophysical sensors in five different sensors combinations; ii) using different machine learning algorithms for prediction and selection of suitable models for each soil attribute evaluated; iii) evaluating the results and the importance of the variables and relate to pedogeomorphological processes. Our main hypothesis is that the combined use of three geophysical sensors data affords a better prediction of soil attributes by different machine learning algorithms and

110 better model performance. Also, this research can provide an important background for geoscience studies and improving geophysical and soil survey procedures.

\section{Material and methods}

\subsection{Study area}

115 The study area is located on a sugarcane farm of 184 hectares, located in São Paulo State, Brazil (23 0' $31.37^{\prime \prime}$ to $22^{\circ} 58^{\prime}$ $53.97^{\prime} \mathrm{S}$ and $53^{\circ} 39^{\prime} 47.81^{\prime}$ to $53^{\circ} 37^{\prime} 25.65^{\prime} \mathrm{W}$ ), in the Capivari River catchment, part of the Paulista Peripheric Depression geomorphological unit (Fig. 1). The lithology is mainly composed by Paleozoic sedimentary rocks, dominant by Itararé formation (siltites/meta-siltites) crossed by intrusive diabase dykes of the Serra Geral Formation. The lowlands are covered by Quaternary alluvial sediments deposited by the Capivari River in ancient fluvial terraces (Fig. 2a). 


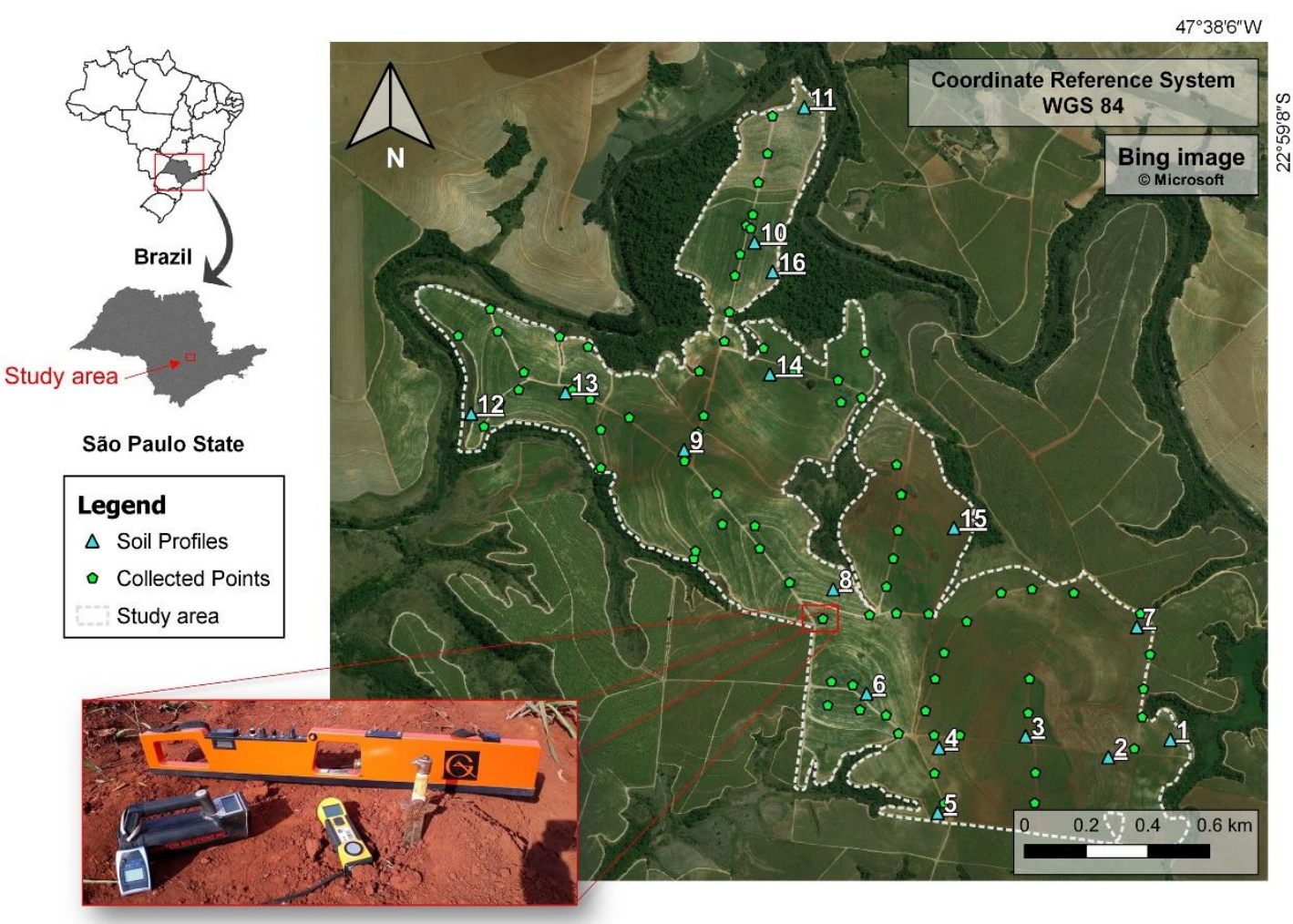

Figure 1. Study area, collected points and geophysical sensors. A - Gamma-ray spectrometer (Radiation Solution - RS 230); B - Susceptibilimeter (KT-10 Terraplus); C - Geonics Ground Conductivity Meter (EM 38).

The heterogeneity of landform and parent materials drove the formation of several soil types (Fig. 2b). Previous soil survey and mapping was performed in the study area by expert pedologists (Bazaglia Filho et al., 2013; Nanni and Demattê, 2006), in which the main soil classes mapped were: Cambisols, Phaeozems, Nitisols, Acrisols and Lixisols (IUSS Working Group WRB, 2015). Besides the soil profiles, 75 subsamples from 75 points $(0-20 \mathrm{~cm}$ layer $)$ were collected by augering for physicochemical analyses, according to Figure 1. 
https://doi.org/10.5194/gmd-2021-153

Preprint. Discussion started: 16 July 2021

(c) Author(s) 2021. CC BY 4.0 License.

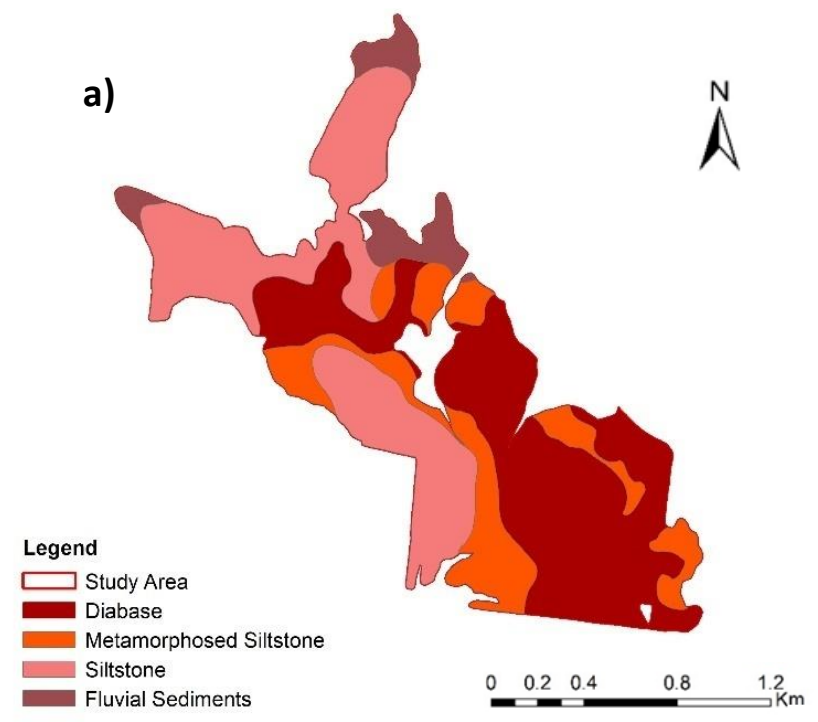

b)
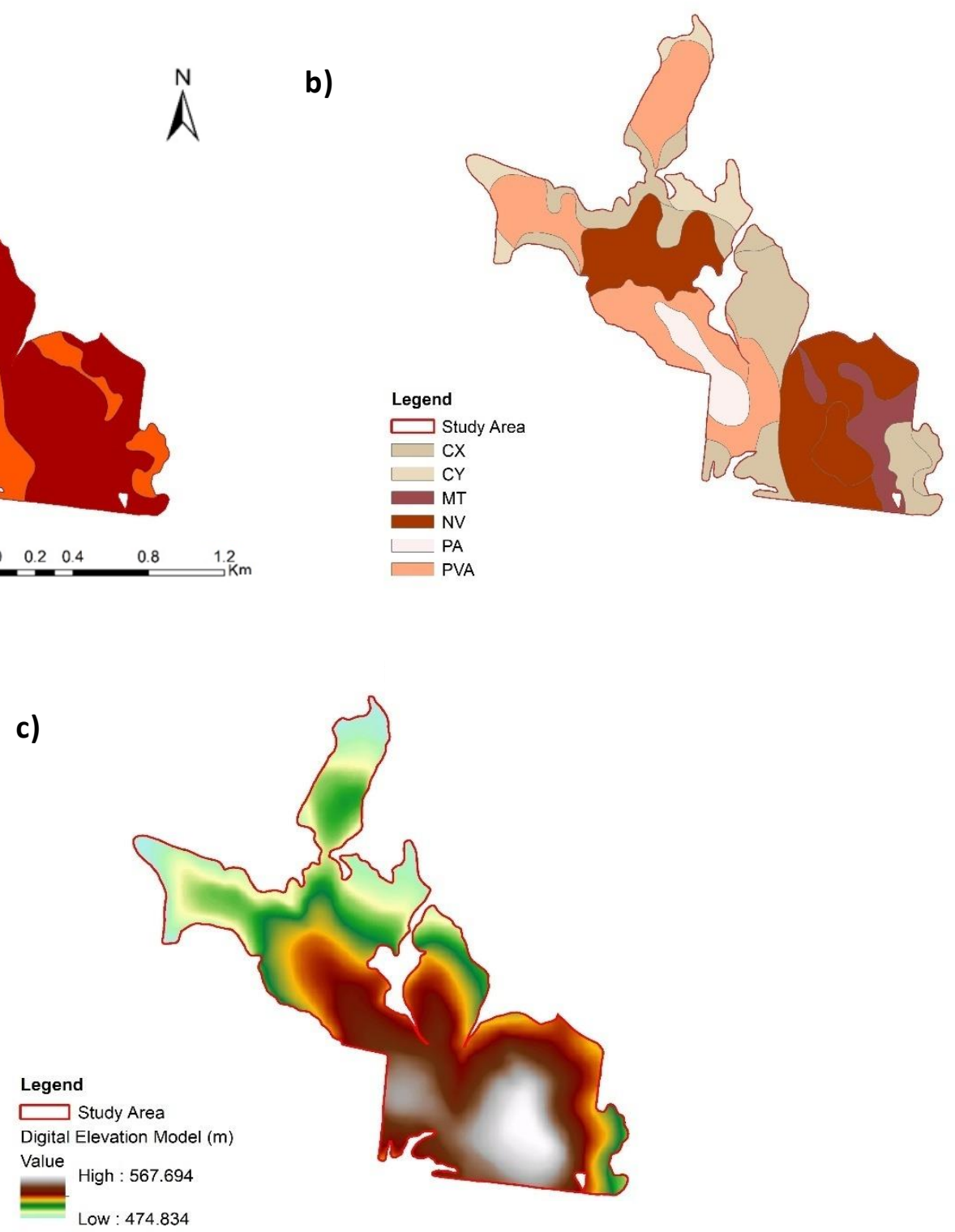

130 Figure 2. a) Geological compartments of landscape. b) Soil classes: CX: Haplic Cambisols, CY: Fluvic Cambisols, MT: Luvic Phaozem, NV: Rhodic Nitisol: PA: Xanthic Acrisol, PVA: Rhodic Lixisol. The geological and Soil classes maps were adapted from Bazaglia Filho et. al. (2012). d) Slope.c) Digital elevation model. 
https://doi.org/10.5194/gmd-2021-153

Preprint. Discussion started: 16 July 2021

(c) Author(s) 2021. CC BY 4.0 License.

(c) (i)

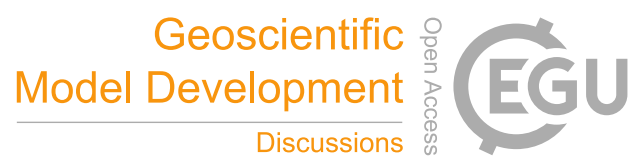

According to the Köppen classification the region's climate is subtropical, mesothermal (Cwa), with an average temperature

from $18{ }^{\circ} \mathrm{C}$ (July - Winter) to $22{ }^{\circ} \mathrm{C}$ (February - Summer), and mean annual precipitation between 1100 and $1700 \mathrm{~mm}$ (Alvares et al., 2013).

\subsection{Laboratory physico-chemical analysis}

For soil physical analyses, the soil samples were firstly air-dried, grounded and sieved to $2 \mathrm{~mm}$ mesh and then, the granulometric analysis were performed. After that, clay, silt and sand contents were determined by the densimeter method

140 (Camargo et al., 1986). Using the granulometry data, the textural groups were determined following EMBRAPA (2011), methodology.

The soil chemical analysis were performed: The exchangeable cations aluminium, calcium and magnesium $\left(\mathrm{Al}^{3+}, \mathrm{Ca}^{2+}\right.$ and $\mathrm{Mg}^{2+}$ ) were determined by $\mathrm{KCl}$ solution $\left(1 \mathrm{~mol} \mathrm{~L}^{-1}\right)$ and quantified by titration (Teixeira et al., 2017). Mehlich-1 solution were used to extract $\mathrm{K}^{+}$, which were quantified by flame photometry. Potential acidity $\left(\mathrm{H}^{+}+\mathrm{Al}^{3}\right)$ were determined using

145 calcium acetate solution $\left(0.5 \mathrm{~mol} \mathrm{~L}^{-1}\right)$ at $\mathrm{pH} 7.0$ and, for the $\mathrm{pH}$ in water determination, the soil:solution ratio of 1:2.5 was used (Teixeira et al., 2017). More details about the analysis methods, can be found in (EMBRAPA, 2017). The determination of soil organic carbon was performed using the Walkley-Black method, by oxidation with potassium the method (EMBRAPA, 2017; Pansu, M., Gautheyrou, J., 2006). Total iron content were determined using selective dissolution by attack with sulfuric acid (EMBRAPA, 2017; Lim, C.H., Jackson, 1986). The resulting extract was used to determine the

150 contents of silicon dioxide $\left(\mathrm{SiO}_{2}\right)$ and titanium dioxide $\left(\mathrm{TiO}_{2}\right)$ EMBRAPA (2017) methodology. All other chemical parameters such as: Base Sum (BS) Cation Exchange Capacity (CEC), Base Saturation (V\%) and Aluminum Saturation $(\mathrm{m} \%)$ were determined using the analytical data obtained previously, following the methodology (EMBRAPA, 2017). The same methodology for physico-chemical soil analysis was used by Mello et al., (2020); Mello et al., (2021).

\section{2.3.1 Radionuclides and gamma-ray spectrometry data}

The radionuclide $\mathrm{K}^{40}$ was quantified in total amount, measured by the absorption energy (1.46 MeV). The thorium $\left(\mathrm{Th}^{232}\right)$ and uranium $\left(\mathrm{U}^{238}\right)$ are quantified by absorption energy, (approximately $2.62 \mathrm{MeV}$ and $1.76 \mathrm{MeV}$, respectively). This quantification is indirectly performed through thallium $\left(\mathrm{Tl}^{208}\right)$ and bismuth $\left(\mathrm{Bi}^{214}\right)$ derived by radioactive decay, respectively for $\mathrm{Th}^{232}$ and $\mathrm{U}^{238}$, which are used by expression eTh and eU (equivalent thorium and uranium respectively).

160 For soil gamma spectrometric characterization, we used the near-gamma-ray spectrometer (GM) model Radiation Solution RS 230 - Radiation Solution INC - Ontario - Canada (Fig. 1A). The sensor is able to quantify the radionuclides eTh and eU concentration in parts per million (ppm), while the $\mathrm{K}^{40}$ is quantified in $\%$ due to its major content in pedosphere. Conventionally, the radionuclides are expressed in $\mathrm{mg} \mathrm{kg}^{-1}$ for $\mathrm{eU}$ and $\mathrm{eTh}$, while for $\mathrm{K}^{40}$ is used \%. The GM detect the gamma-ray radiation emission down to $30-60 \mathrm{~cm}$ depth, and varies mainly with soil bulk density and moisture content

165 (Wilford et al., 1997; Taylor et al., 2002; Beamish, 2015). 
Firstly, the GM was automatically calibrated by switching on and leaving the sensor on the ground surface for five minutes until readings of eU, eTh and, $\mathrm{K}^{40}$ contents be stabilized (Radiation Solutions, 2009). The measurements of radionuclides were taken in the "assay-mode" of highest precision for quantification, which the GM was kept at the soil surface for two minutes, in each sampling point (79 total collect points) (Fig. 1). The geographic position was taken by a GPS coupled in the GM (GPS - Radiation Solution INC - Ontario - Canada - precision of 1m). The collected data in all points were concatenated with their respective information from the soil physico-chemical analyzes for later geoprocessing. The same methodology for gamma-ray spectrometric data acquisition has been applied by Mello et al., (2021).

\subsubsection{Magnetic susceptibility (к)}

175 For soil magneitic susceptibility $(\kappa)$ characterization, surface readings were recorded at all 79 points using a geophysical susceptibility meter sensor (KT10 - Terraplus) (Fig. 1b). This sensor is able to measure $\kappa$ to a depth of $2 \mathrm{~cm}$ below the soil surface, with a precision $10^{-6} \mathrm{SI}$ units, expressed in $\mathrm{m}^{3} \mathrm{~kg}^{-1}$. To perform the readings, the sensor was firstly calibrated by determining the frequency of the outdoor oscillator. Then, we followed the sequence required to obtain the measurements performed in three steps: 1- determine the frequency and amplitude of the oscillator in free air; 2 - The frequency and amplitude of the oscillator were measured with the coil placed directly on the soil surface (sample) outcrop; 3 - We repeated the step 1, and then the results were displayed. More information about the procedures see Sales, (2021). We performed the readings at scanner mode, which uses the best geometric correlation to direct $\kappa$ readings, providing fast and accurate quantification. We performed three readings in triangulation around each augering/collected point and used the mean value of $\kappa$ in all our analyses. This procedure was adopted to reduce noise. The same methodology for $\kappa$ readings was performed by Mello et al., (2020).

\subsubsection{Apparent electrical conductivity (ECa)}

The ECa measurements was performed by the conductivity meter Geonics EM38 (Geonics Ltd., Mississauga, Ontario, Canada) (McNeill, 1986) (Fig. 1C). The EM38 provides measurement of the quad-phase (conductivity) without any requirement for soil-to-instrument contact (Geonics, 2002). The ECa measurements units are reported in $\mathrm{mSm}^{-1}$. Firstly, the EM38 was appropriately calibrated following the instructions of Heil and Schmidhalter, (2019), section 3.1.1. The values of the ECa are a function of calibration, coil orientation, and coil separation (Heil and Schmidhalter, 2019). More details about EM38 operation is discussed in Hendrickx and Kachanoski, (2002).

After calibration, the ECa readings were performed at all 75collection points (Fig. 1), using the EM38 at vertical dipole orientation, which provide data from effective soil depth at $1.5 \mathrm{~m}$. The field incursions to collect the data were undertaken in dry season, bare soil and, at same hour interval during the day to reduce environmental variables influence. Also, all metal objects were kept distant from the EM 38 to avoid readings interferences.

Table 1. Terrain variables generated from the digital elevation model 
https://doi.org/10.5194/gmd-2021-153

Preprint. Discussion started: 16 July 2021

(c) Author(s) 2021. CC BY 4.0 License.

(c) (i)

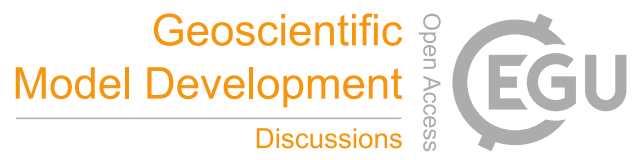

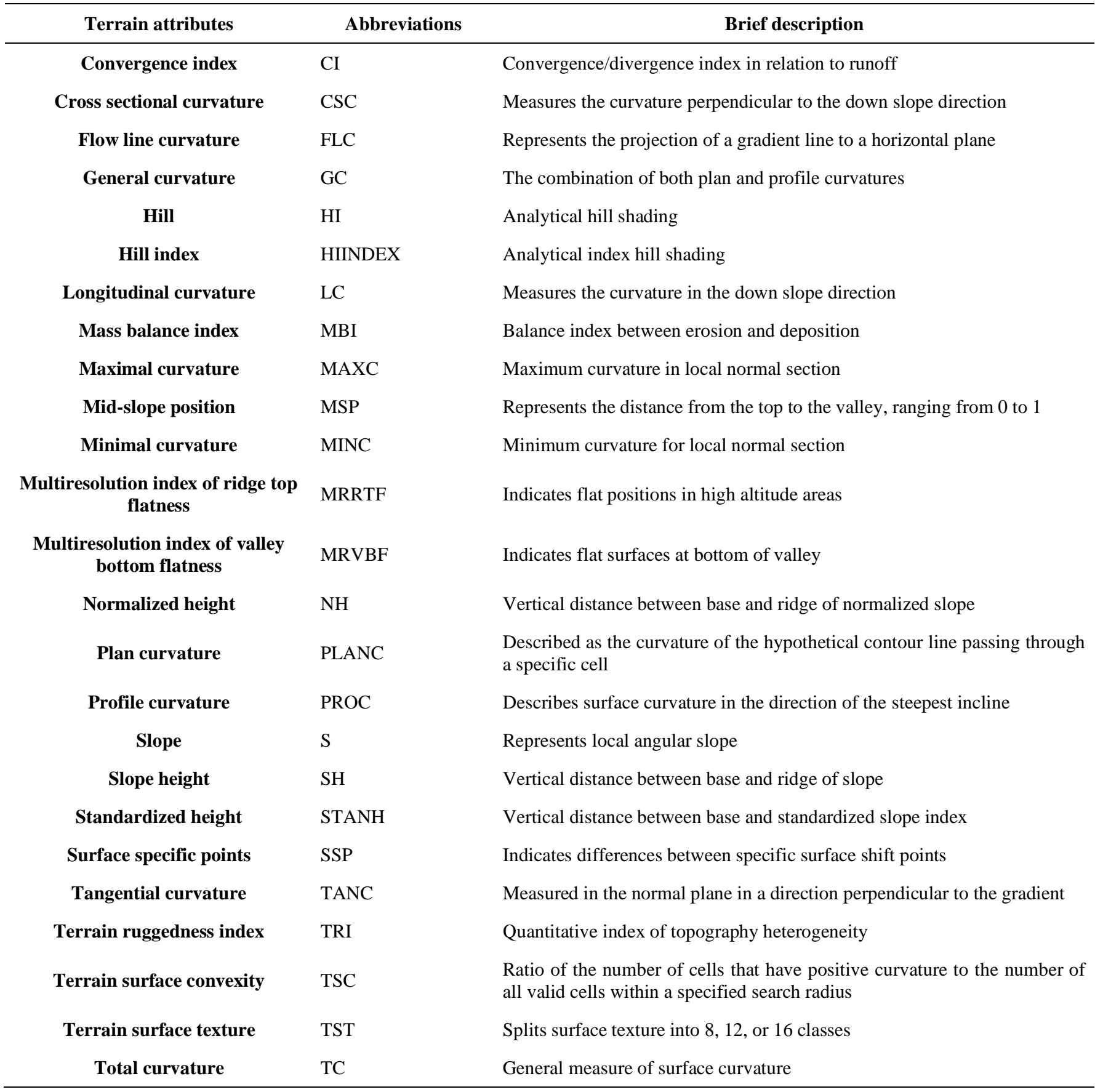


https://doi.org/10.5194/gmd-2021-153

Preprint. Discussion started: 16 July 2021

(c) Author(s) 2021. CC BY 4.0 License.

(c) (i)

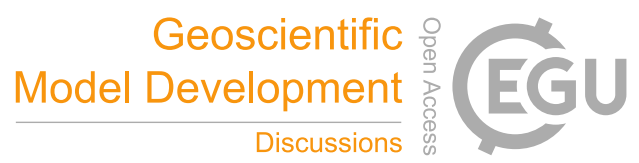

Cont. table 1

\begin{tabular}{|c|c|c|}
\hline Terrain attributes & Abbreviations & Brief description \\
\hline Topographic position index & TPI & $\begin{array}{l}\text { Difference between a point elevation with } \\
\text { surrounding elevation }\end{array}$ \\
\hline Valley depth & VD & $\begin{array}{l}\text { Calculation of vertical distance at drainage } \\
\text { base level }\end{array}$ \\
\hline Valley & VA & $\begin{array}{l}\text { Calculation fuzzy valley using the Top Hat } \\
\text { approach }\end{array}$ \\
\hline Valley Index & VA & $\begin{array}{l}\text { Calculation fuzzy valley index using the } \\
\text { Top Hat approach }\end{array}$ \\
\hline Topographic wetness index & TWI & $\begin{array}{l}\text { Describes the tendency of each cell to } \\
\text { accumulate water in relief }\end{array}$ \\
\hline
\end{tabular}

\section{2.3.5. Modelling processing}

The modeling process is demonstrated in the flowchart (Fig. 3). The modeling can be divided into two parts: selection of covariates and training/test of the data. In the selection phase, the algorithm tries to produce the ideal set of covariates, following the principle of parsimony. This is performed by removing highly correlated variables, evaluating the importance of covariables and remove variables that have minor importance in training the model in the prediction process of each

210 algorithm. Darst et al., (2018), considered joint application of the methods of selection of covariates by correlation and importance (RFE), since only the use RFE reduces the effect of highly correlated covariates, but does not eliminate it. 
https://doi.org/10.5194/gmd-2021-153

Preprint. Discussion started: 16 July 2021

(c) Author(s) 2021. CC BY 4.0 License.

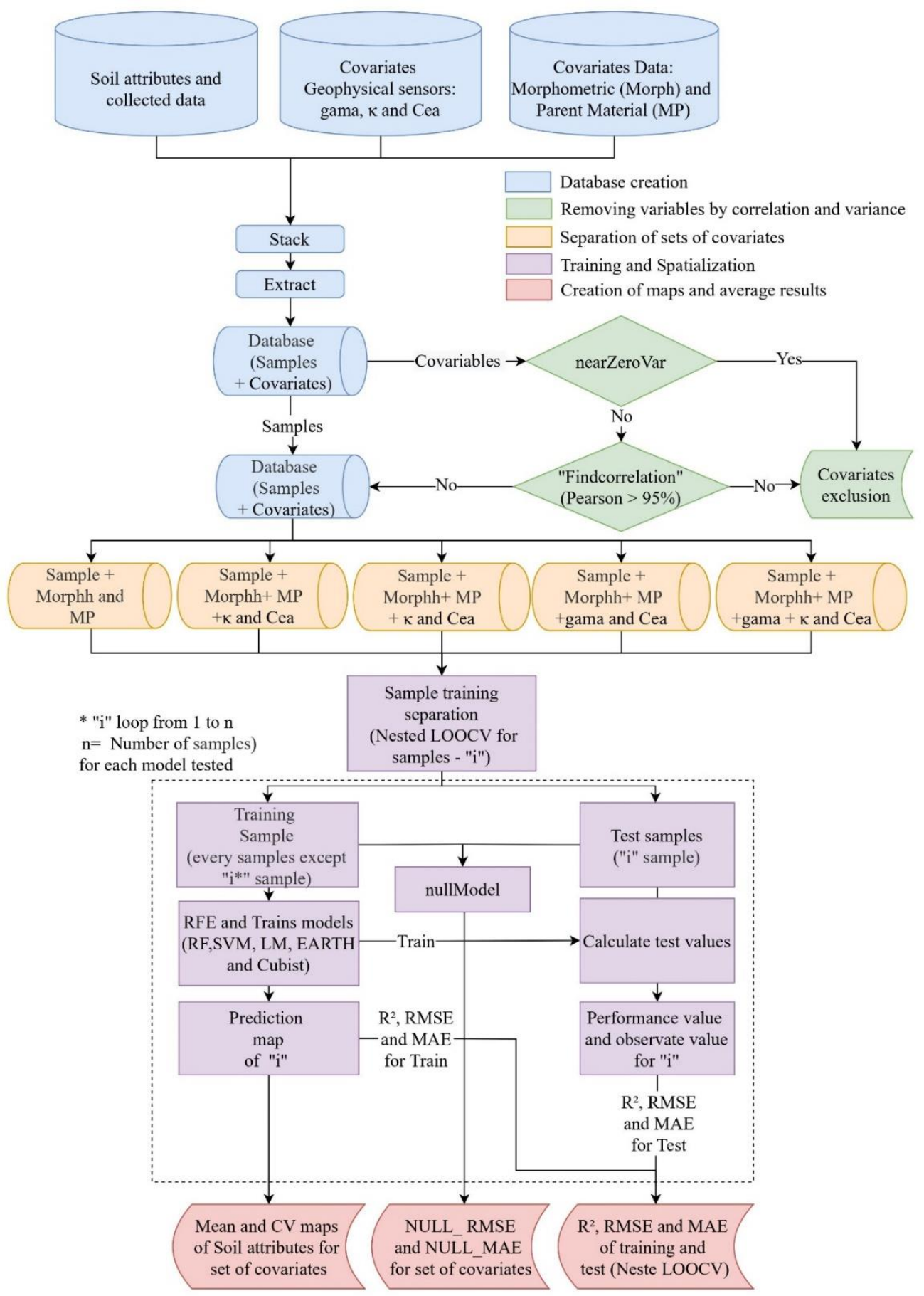

Figure 3. Methodological flowchart showing the sequence of methodologies applied for soil and geophysical attributes prediction. The most accurate model between Cubist, Random Forests (RF), Support Vector Machines (SVM), Earth and 215 Linear Models (LM) was selected to model and map the geophysical and soil attributes maps. 
The correlation selection process was used to calculate the correlation of the set of covariates and covariables, which were evaluated with a correlation greater than the limit (Pearson test $>95 \%$ ). The pairs that showed higher values are evaluated due to their correlation with the complete set of covariates, eliminating the one with the highest value of the sum of the absolute correlation with the other covariables that started in this process. For this phase we applied the cor and find correlation functions of the "stats" (Hothorn, 2021) and "caret" (Kuhn et al., 2020) packages, in $R$ software, respectively (Kuhn and Johnson, 2013). In this phase, the covariables: curv_cross_secational and curv_longitudinal were eliminated for all tested sensor sets. The set of covariables that passed this phase joined the samples followed by the separation of samples from training and test.

225 The separation of training and test was performed using the "nested" leave one out (nested LOOCV) method (Clevers et al., 2007; Honeyborne et al., 2016; Rytky et al., 2020). It is important to highlight that our number of soil samples and readings with geophysical sensors is small (75), due to several difficulties encountered in the field in data collection (high sugar cane size, sloping terrain, dense forest, etc.). In this sense, the nested LOOCV method is indicated for small sample sets (values near 100 samples) to which other validation/test methods (as holdout validation) would not be viable due to the low sample set in the test and /or training group (Ferreira et al., 2021). This is one of the main innovations of this research.

The nested LOOCV method is a double loop process, where in the first loop the model is trained with a data set of size n-1, and the test is done in the second loop with the missing sample and used to validate the training performance (Jung et al., 2020; Neogi and Dauwels, 2019). The final result of the performance of the machine learning algorithm will be the mean performance indicators for all points (Training / test). This is a robust method to evaluate the performance of the algorithm and detects possible samples with problems in the collections or outliers. The training set generated in each loop went through the process of selecting covariates for importance and subsequent training.

The selection of covariates by importance is made using the back forward method using the Recursive Feature Elimination (RFE) function contained in the "caret" package (Kuhn and Johnson, 2013). The RFE is unique for each algorithm, the result being the set of selected covariates used in the prediction of the final model in the same algorithm. The RFE is a selection method that eliminates the variables that least contribute to the model, based on a measure of importance for each algorithm (Kuhn and Johnson, 2013). The algorithm will be applied to complete sets of data (variable by the set of tested sensors) and 18 more subsets 5,6,7, .. 19, 20 and 30 covariables. Reaching a set of fewer variables (more parsimonious), achieving better prediction performance. The optimization of the ideal covariate subset was based on leave one out (LOOCV), a repetition and 5 values of each of the internal hype parameters of each tested algorithm (tuneLength). The hyperparameters of each algorithm are described in the caret package manual in chapter 6. "Models described" available at https://topepo.github.io/caret/train-models-by-tag.html. The metric for choosing the best subset for each model were $\mathrm{R}^{2}$. For this work, five algorithms were tested: Random Forests (RF), Cubist (C), Support Vector Machines (SVM), Generalized Linear Models ( $\mathrm{lm})$. The choice was made with the use of families of different algorithms in mind, and using linear and non- 
linear algorithms. The algorithms used are commonly used in soil attribute mapping studies. At the end of the selection phase by importance, the most optimized set of covariates for training was generated for each algorithm.

The training was performed with the variables selected in the previous step each tested algorithm by using leave one out (LOOCV) and ten repetitions. Five values of each of the internal hype parameters of each tested algorithm were also tested (tuneLength). At the end of the training phase, a sample prediction was made that was not used in the training and the result was saved for the performance study. The performance of the prediction of the algorithms and set of sensors was performed with a set of samples from the outer loop of the nested LOOCV method. Three evaluation parameters are used: R-square R2 (Eq. (1)), root mean squared error - RMSE (Eq. (2)), mean absolute error - MAE, (Eq. (3)).

$$
\begin{gathered}
\mathrm{R}^{2}=\frac{\left[\sum(\text { Qpred }-\overline{\text { Qpred }}) \times(\text { Qobs }-\overline{\text { Qobs }})\right]^{2}}{\left[\sum(\text { Qpred }-\overline{\text { Qpred }})^{2}\right] \times\left[\sum(\text { Qobs }-\overline{\text { Qobs }})^{2}\right]} \\
\text { RMSE }=\sqrt{\frac{1}{\mathrm{n}} \times \sum(\text { Qobs }- \text { Qpred })^{2}} \\
\text { MAE }=\frac{1}{\mathrm{n}} \times \sum \mid \text { Qpred }- \text { Qobs } \mid
\end{gathered}
$$

For comparison purposes, null model values (NULL_RMSE and NULL_MAE) were also calculated. The null model considers using the average value quantified by the collected samples (EQ. 4 and EQ. 5). This methodology is widely used and spatialization processes in kriging when the variable in which spatialization is desired has spatial dependence (pure nugget effect).

$$
\begin{aligned}
& R M S E_{-} N U L L=\left[\frac{1}{N} \sum_{i=1}^{N}\left(\underline{O m}-O_{i}\right)^{2}\right]^{\frac{1}{2}} \\
& N U L L \_M A E=\frac{1}{\mathrm{n}} \times \sum \underline{\underline{\text { train }_{i}}}-Q_{\text {obs }} \mid
\end{aligned}
$$

The NULL_RMSE and NULL_MAE values lower than those observed in the prediction of the algorithm in the validation phase show that the use of mean of the samples of the desired propriety consist with the model created by the algorithms of machine learning. The NULL_RMSE and NULL_MAE were calculated using the nullMode function of the caret package (Kuhn et al., 2020). 
https://doi.org/10.5194/gmd-2021-153

Preprint. Discussion started: 16 July 2021

(c) Author(s) 2021. CC BY 4.0 License.

270 The final result of the performance of the algorithms of each attribute was made using the 75 loops, the training results being the average of the performance and the results of the test samples calculated from the 75 external loops results using equations 1, 2 and 3. The importance of the algorithms was calculated by the caret package (Kuhn and Johnson, 2013), each model presents its creation methodology. The final importance for each algorithm and attribute, was created from the importance created in the loop, being the average of the importance of the 75 repetitions.

\section{Results}

\subsection{Geophysical sensors combinations, models performance, uncertainty and covariates importance}

The worst performance in modeling soil attributes occurred excluding the use of geophysical sensors, where only parent material and terrain attributes were used (Table 2). In this case, the algorithms selected particular groups of terrain attributes

280 for modelling each soil attributes (Table 1).

Table 2. Models' performance for non-use geophysical sensors, for all soil attributes, based on $\mathrm{R}^{2}$, RMSE, MAE and NULL_RMSE

\begin{tabular}{|c|c|c|c|c|c|c|c|c|c|}
\hline \multicolumn{10}{|c|}{ Non-use of geophysical sensors } \\
\hline & & Clay & Sand & $\mathrm{Fe}_{2} \mathrm{O}_{3}$ & $\mathrm{TiO}_{2}$ & $\mathrm{SiO}_{2}$ & CEC & BS & OM \\
\hline \multirow{4}{*}{$\mathbf{R}^{\mathbf{2}}$} & Random Forest & 0.38 & 0.284 & 0.159 & 0.12 & 0.12 & 0.149 & 0.131 & 0.000 \\
\hline & Cubist & 0.386 & 0.292 & 0.12 & 0.125 & 0.174 & 0.053 & 0.028 & 0.001 \\
\hline & SVM & 0.259 & 0.278 & 0.279 & 0.226 & 0.128 & 0.195 & 0.113 & 0.004 \\
\hline & LM & 0.285 & 0.225 & 0.217 & 0.16 & 0.247 & 0.002 & 0.003 & 0.051 \\
\hline \multirow{5}{*}{ RMSE $^{2}$} & Random Forest & 136.778 & 185.398 & 61.686 & 12.229 & 41.701 & 41.3 & 20.206 & 8.469 \\
\hline & Cubist & 140.103 & 192.867 & 66.432 & 12.424 & 41.323 & 50.065 & 22.853 & 8.126 \\
\hline & SVM & 154.406 & 190.151 & 59.453 & 11.621 & 42.595 & 41.141 & 20.396 & 8.045 \\
\hline & LM & 156.646 & 215.355 & 66.357 & 13.118 & 38.976 & 997.529 & 1189.64 & 7.702 \\
\hline & NULL_RMSE & 140.885 & 176.521 & 53.341 & 10.239 & 35.450 & 36.139 & 17.142 & 6.158 \\
\hline \multirow{5}{*}{ MAE } & Random Forest & 110.485 & 149.205 & 40.742 & 8.206 & 31.757 & 28.931 & 16.3 & 6.357 \\
\hline & Cubist & 108.284 & 148.8 & 44.028 & 8.294 & 31.715 & 33.168 & 18.271 & 4.813 \\
\hline & SVM & 122.397 & 147.07 & 36.812 & 7.051 & 31.432 & 27.072 & 17.012 & 5.992 \\
\hline & LM & 119.139 & 169.218 & 43.673 & 8.749 & 29.458 & 149.114 & 158.638 & 5.719 \\
\hline & NULL_MAE & 119.751 & 153.803 & 41.578 & 8.074 & 29.534 & 27.187 & 14.425 & 4.813 \\
\hline
\end{tabular}

The Cubist algorithm showed the best performance to predict soil texture, clay $\left(R^{2}\right.$ of 0.386$)$ and sand $\left(R^{2}\right.$ of 0.292$)$ content, with the highest $\mathrm{R}^{2}$ and lowest RMSE and MAE, concomitantly (Table 2). The importance of covariates to sand content 
https://doi.org/10.5194/gmd-2021-153

Preprint. Discussion started: 16 July 2021

(c) Author(s) 2021. CC BY 4.0 License.

(c) (1)

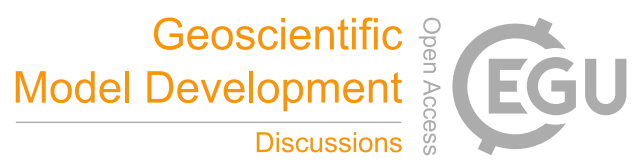

prediction showed that minimal curvature, was the most important variable, contributing $100 \%$ on the decreasing of the mean accuracy. On the other hand, for clay content the most important variable was parent material. In addition, for clay and sand the tangential curvature and DEM showed importance higher than 50\% (Fig. 4).

The SVM algorithm presented moderate performance, for $\mathrm{Fe}_{2} \mathrm{O}_{3}\left(\mathrm{R}^{2}\right.$ 0.279), $\mathrm{TiO}_{2}\left(\mathrm{R}^{2}\right.$ 0.226); whereas for $\mathrm{SiO}_{2}$, the $\mathrm{LM}$ presented the best result, also with a moderate performance $\left(\mathrm{R}^{2}\right.$ 0.247) (Table 2). The selected models presented the highest $\mathrm{R}^{2}$ and lowest RMSE and MAE, simultaneously. The most important covariates for $\mathrm{Fe}_{2} \mathrm{O}_{3}$ and $\mathrm{TiO}_{2}$ prediction by the SVM model, were parent material (100\%) and DEM (more than 50\%). For $\mathrm{SiO}_{2}$ prediction by $\mathrm{LM}$ model, the most important covariates were DEM (100\%) and standardized height (90\%), while parent material contributed with 40\% (Fig. 4).

For cation exchange capacity (CEC) the model with the best performance, after 75 runs was SVM, ( $\mathrm{R}^{2}$ of 0.223$)$ (Table 2). The most important covariates for CEC prediction to mean accuracy were DEM (100\%), topographic wetness index (80\%) and parent material (75\%) (Fig. 4). 
https://doi.org/10.5194/gmd-2021-153

Preprint. Discussion started: 16 July 2021

(c) Author(s) 2021. CC BY 4.0 License.
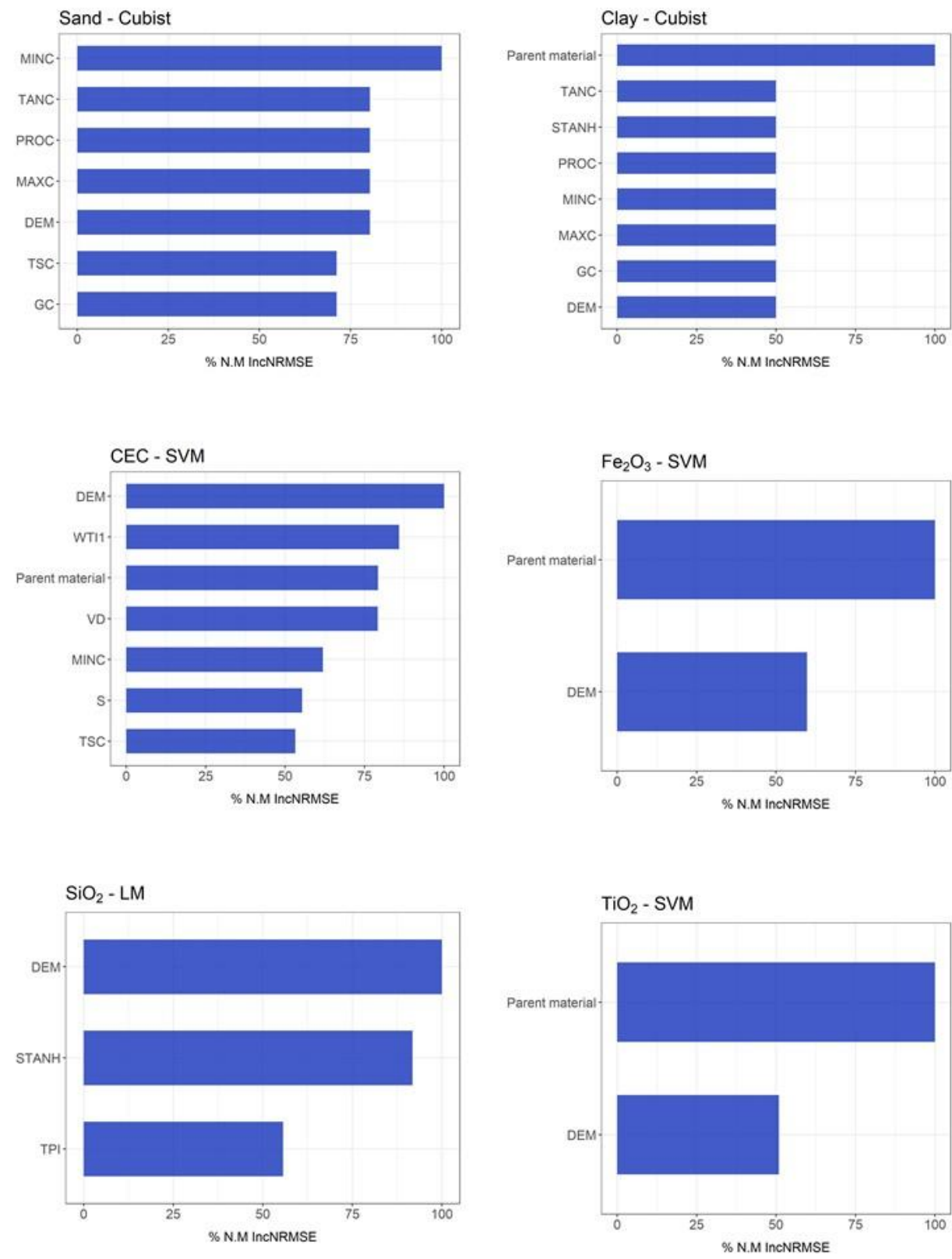

Figure 4. Variable Importance for Non-use of geophysical sensors (only variables that contributed more than 50\% are presented here (for further details see supplementary material). 
In all models, there was a very low performance in the prediction of base saturation (BS) and organic matter (OM), with $\mathrm{R}^{2}$ between 0.001 and 0.1 (Table 2, 3, 4, 5 and 6).

The different combinations of geophysical sensors that contributed to moderate modeling performance of soil attributes were: Susceptibilimeter + Conductivimeter $(S+C)$, Gamma-ray spectrometer + Conductivimeter $(G+C)$, Combined use of the three geophysical sensors $\left(\mathrm{G}+\mathrm{S}+\mathrm{C}\right.$ ) (Tables 3, $\mathbf{4}$ and 6, respectively). The $\mathrm{R}^{2}$ values presented some variation between the $\mathrm{R}^{2}$ of best combination of geophysical sensors and the lowest $\mathrm{R}^{2}$ values from the without the use geophysical sensors in predictive models (Tables 3, 4 and 6). Among all the values of $\mathrm{R}^{2}$ evaluated for this session, we consider all the highest values and, among the highest values the lowest values we considered the worst result.

Table 3. Models' performance for combined use of susceptibilimeter and conductivimeter, for all soil attributes, based on $\mathrm{R}^{2}$, RMSE, MAE and NULL_RMSE

\begin{tabular}{|c|c|c|c|c|c|c|c|c|c|}
\hline \multicolumn{10}{|c|}{ Susceptibilimeter + Conductivimeter } \\
\hline & & Clay & Sand & $\mathrm{Fe}_{2} \mathrm{O}_{3}$ & $\mathrm{TiO}_{2}$ & $\mathrm{SiO}_{2}$ & CEC & BS & OM \\
\hline \multirow{4}{*}{$\mathbf{R}^{2}$} & Random Forest & 0.444 & 0.334 & 0.314 & 0.316 & 0.141 & 0.139 & 0.138 & 0.032 \\
\hline & Cubist & 0.433 & 0.365 & 0.407 & 0.338 & 0.25 & 0.178 & 0.079 & 0.077 \\
\hline & SVM & 0.484 & 0.322 & 0.153 & 0.263 & 0.169 & 0.223 & 0.065 & 0.039 \\
\hline & LM & 0.394 & 0.312 & 0.383 & 0.262 & 0.101 & 0.124 & 0.002 & 0.056 \\
\hline \multirow{5}{*}{ RMSE $^{2}$} & Random Forest & 129.619 & 178.22 & 55.378 & 10.531 & 41.116 & 41.878 & 19.821 & 8.079 \\
\hline & Cubist & 136.834 & 178.253 & 52.416 & 10.583 & 39.138 & 41.91 & 21.543 & 7.494 \\
\hline & SVM & 127.598 & 181.811 & 64.573 & 11.052 & 42.22 & 40.134 & 22.307 & 7.924 \\
\hline & LM & 139.463 & 190.515 & 54.36 & 11.622 & 46.013 & 48.52 & 1219.091 & 8.007 \\
\hline & NULL_RMSE & 140.885 & 176.521 & 53.341 & 10.239 & 35.450 & 36.139 & 17.142 & 6.158 \\
\hline \multirow{5}{*}{ MAE } & Random Forest & 102.841 & 145.441 & 34.357 & 6.457 & 30.54 & 29.354 & 15.824 & 5.949 \\
\hline & Cubist & 105.12 & 139.737 & 32.246 & 6.593 & 28.954 & 28.912 & 17.372 & 5.713 \\
\hline & SVM & 92.812 & 146.016 & 40.303 & 6.65 & 31.153 & 26.689 & 18.953 & 6.108 \\
\hline & LM & 106.083 & 153.815 & 36.79 & 8.199 & 33.218 & 33.024 & 161.284 & 6.04 \\
\hline & NULL_RMSE & 119.751 & 153.803 & 41.578 & 8.074 & 29.534 & 27.187 & 14.425 & 4.813 \\
\hline
\end{tabular}

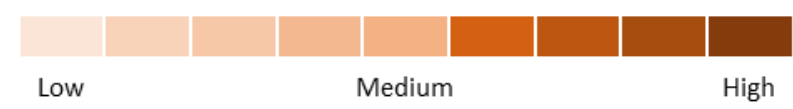

Clay and sand content in $\mathrm{g} \cdot \mathrm{kg}^{-1} ; \mathrm{Fe}_{2} \mathrm{O}_{3}, \mathrm{TiO}_{2}$ and $\mathrm{SiO}_{2}$ in g.kg ${ }^{-1} \mathrm{CEC}$ in $\mathrm{mmol}_{\mathrm{c}} \mathrm{dm}^{-3}$; Abbreviations: CEC: Cation Exchange Capacity; OM g.dm ${ }^{-3}$; BS: mmolc $\mathrm{dm}^{-3}$. 
https://doi.org/10.5194/gmd-2021-153

Preprint. Discussion started: 16 July 2021

(c) Author(s) 2021. CC BY 4.0 License.

Table 4. Models' performance for combined use of gamma-ray spectrometer and conductivimeter, for all soil attributes, based on $\mathrm{R}^{2}$, RMSE, MAE and NULL_RMSE

\begin{tabular}{|c|c|c|c|c|c|c|c|c|c|}
\hline \multicolumn{10}{|c|}{ Gamma-ray spectrometer + Conductivimeter } \\
\hline & & Clay & Sand & $\mathrm{Fe}_{2} \mathrm{O}_{3}$ & $\mathrm{TiO}_{2}$ & $\mathrm{SiO}_{2}$ & CEC & BS & OM \\
\hline \multirow{4}{*}{$\mathbf{R}^{2}$} & Random Forest & 0.378 & 0.318 & 0.22 & 0.248 & 0.16 & 0.14 & 0.133 & 0.001 \\
\hline & Cubist & 0.433 & 0.265 & 0.282 & 0.189 & 0.163 & 0.077 & 0.065 & 0 \\
\hline & SVM & 0.406 & 0.3 & 0.158 & 0.048 & 0.17 & 0.241 & 0.068 & 0.059 \\
\hline & LM & 0.338 & 0.188 & 0.249 & 0.171 & 0.178 & 0.002 & 0.003 & 0.047 \\
\hline \multirow{5}{*}{ RMSE $^{2}$} & Random Forest & 137.097 & 179.808 & 58.829 & 11.011 & 40.256 & 41.464 & 19.889 & 8.567 \\
\hline & Cubist & 134.231 & 197.657 & 56.918 & 12.026 & 42.209 & 47.809 & 21.704 & 8.356 \\
\hline & SVM & 134.035 & 182.644 & 61.758 & 13.076 & 40.493 & 40.463 & 21.586 & 7.72 \\
\hline & LM & 146.116 & 225.909 & 62.442 & 13.035 & 41.555 & 1499.11 & 33.64 & 7.738 \\
\hline & NULL_RMSE & 140.885 & 176.521 & 53.341 & 10.239 & 35.450 & 36.139 & 17.142 & 6.158 \\
\hline \multirow{5}{*}{ MAE } & Random Forest & 108.636 & 145.511 & 38.867 & 7.265 & 31.095 & 28.539 & 15.812 & 6.443 \\
\hline & Cubist & 105.954 & 160.722 & 37.335 & 8.241 & 32.419 & 33.06 & 17.471 & 6.07 \\
\hline & SVM & 106.779 & 148.469 & 39.185 & 8.197 & 32.189 & 26.449 & 17.325 & 5.578 \\
\hline & LM & 117.816 & 181.07 & 42.121 & 9.198 & 32.035 & 207.159 & 24.294 & 5.806 \\
\hline & NULL_RMSE & 119.751 & 153.803 & 41.578 & 8.074 & 29.534 & 27.187 & 14.425 & 4.813 \\
\hline
\end{tabular}

Clay and sand content in g.kg ${ }^{-1} ; \mathrm{Fe}_{2} \mathrm{O}_{3}, \mathrm{TiO}_{2}$ and $\mathrm{SiO}_{2}$ in g.kg- ${ }^{-1} \mathrm{CEC}$ in $\mathrm{mmol}_{\mathrm{c}} \mathrm{dm}^{-3}$; Abbreviations: CEC: Cation Exchange Capacity; OM g.dm ${ }^{-3}$; BS: mmolc $\mathrm{dm}^{-3}$.

For clay, the model with the best performance was the SVM algorithm $\left(\mathrm{R}^{2}\right.$ 0.484) by S + C (Table 3), while the worst was by the Cubist algorithm $\left(\mathrm{R}^{2} 0.38\right)$ by $(\mathrm{G}+\mathrm{S}+\mathrm{C})$ (Table 6). For sand, the best model performance was the Cubist algorithm $\left(\mathrm{R}^{2} 0.365\right)$ by $\mathrm{S}+\mathrm{C}$ (Table 3) and the worst also by Cubist $\left(\mathrm{R}^{2} 0.387\right)$ by $(\mathrm{G}+\mathrm{S}+\mathrm{C})$. The most important covariates for clay prediction by the SVM model in S $+C$ sensors combination were magnetic susceptibility $(\kappa)(100 \%)$ and parent material

335 (90\%) (Fig. 5). For clay prediction by the Cubist model in $\mathrm{G}+\mathrm{S}+\mathrm{C}$ sensors combination, the most important covariate was parent material (100\%) (Fig. 6). With respect to sand prediction, the most important covariates by the Cubist model in $\mathrm{S}+\mathrm{C}$ were minimal curvature (100\%) and magnetic susceptibility (к) (80\%) (Fig. 5) On the other hand, for $\mathrm{G}+\mathrm{S}+\mathrm{C}$, the covariates that most contributed for sand prediction were DEM (100\%), general curvature (80\%) and minimal curvature (75\%) (Fig. 6). 
https://doi.org/10.5194/gmd-2021-153

Preprint. Discussion started: 16 July 2021

(c) Author(s) 2021. CC BY 4.0 License.

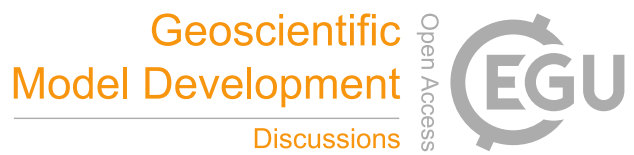
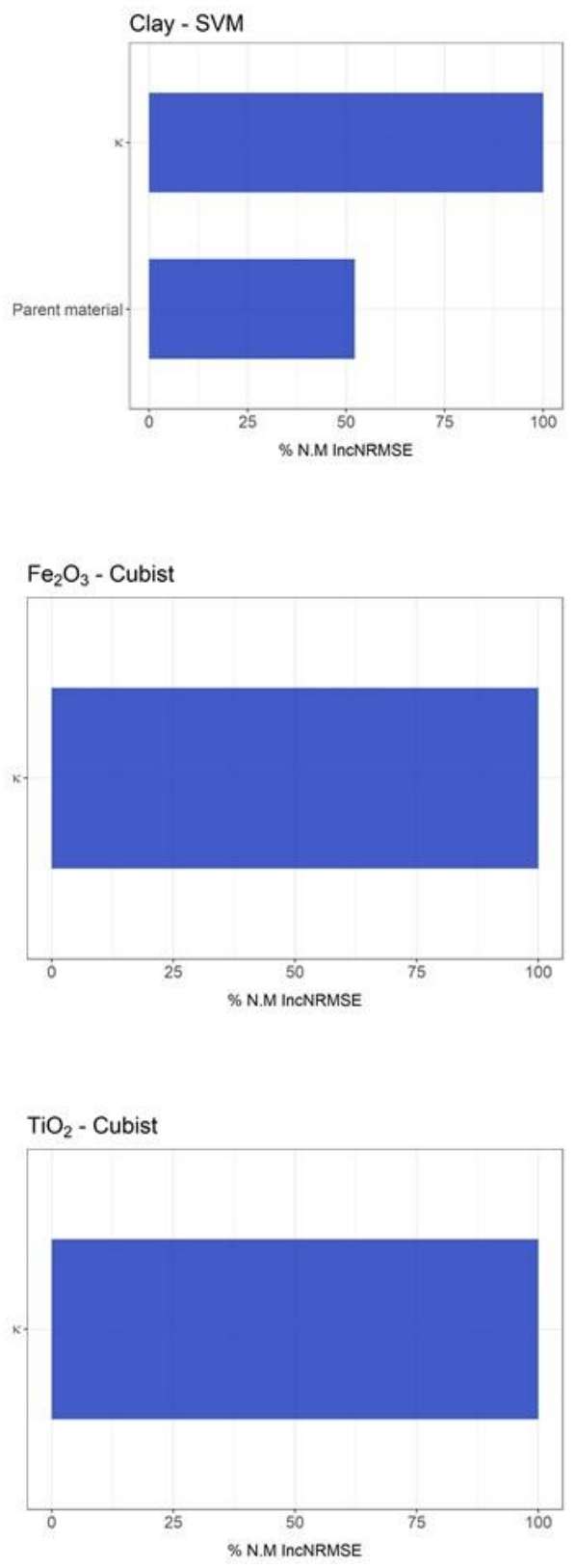
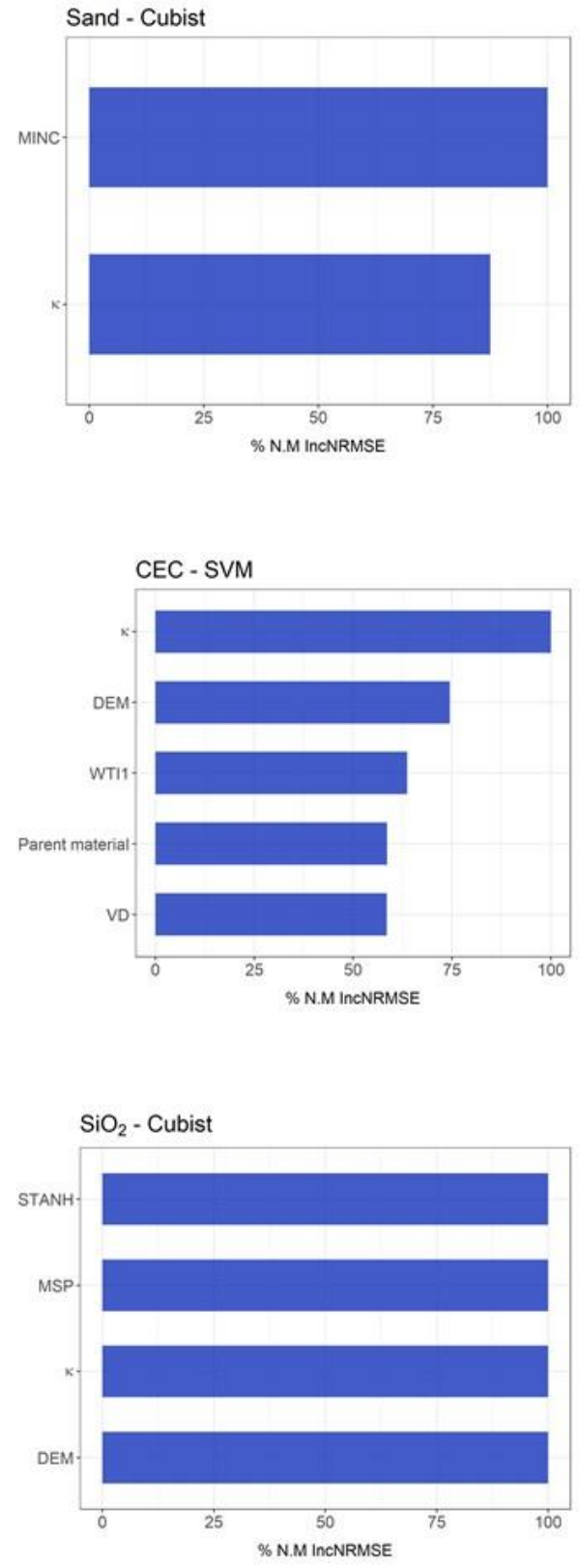

Figure 5. Variable Importance for Susceptibilimeter + Conductivimeter sensors (only variables that contributed more than $50 \%$ are presented here (for further details see supplementary material). 
https://doi.org/10.5194/gmd-2021-153

Preprint. Discussion started: 16 July 2021

(c) Author(s) 2021. CC BY 4.0 License.

\section{Geoscientific 웡 Model Development \\ Discussions}
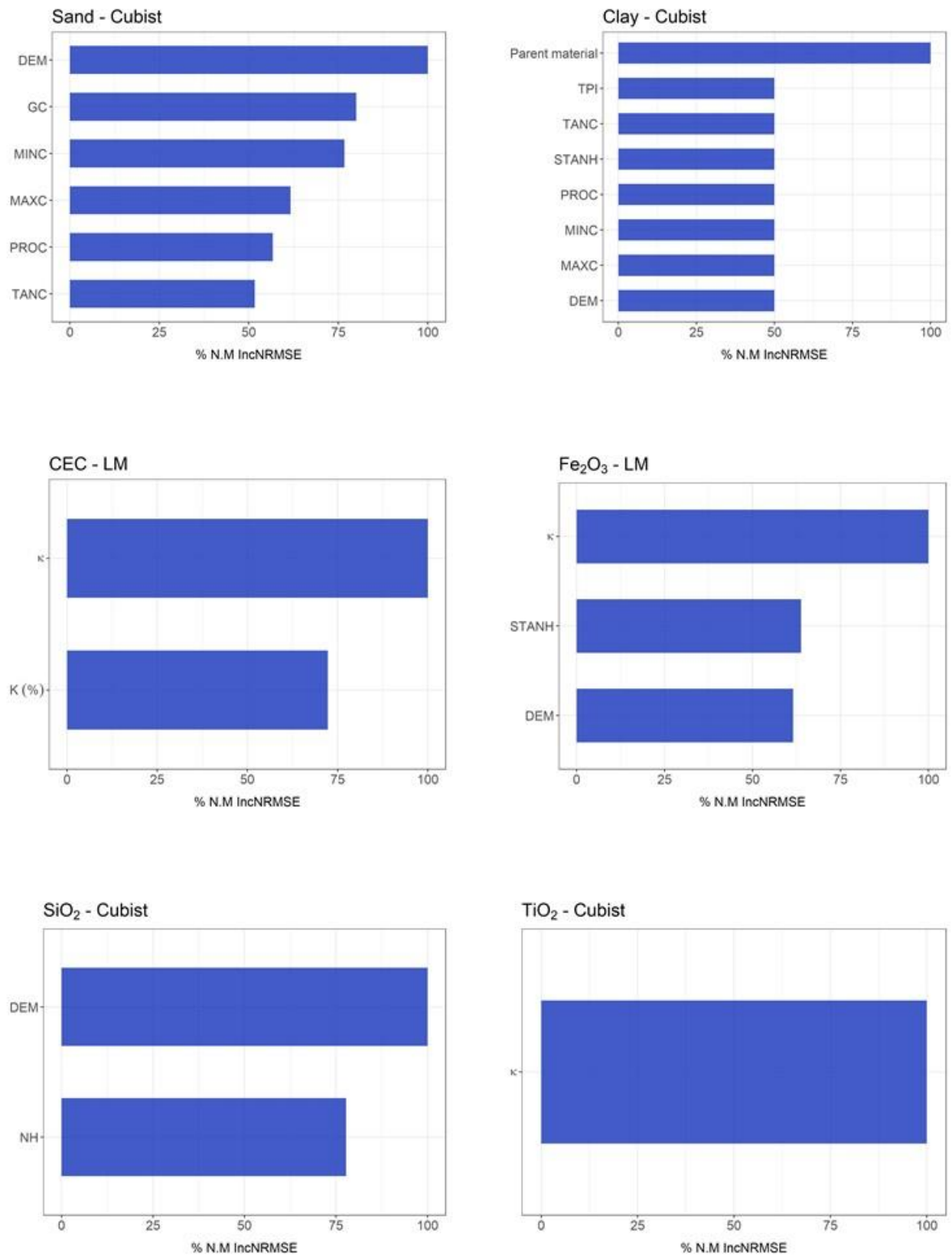

Figure 6. Variable Importance for Combined use of the three geophysical sensors (only variables that contributed more than $34550 \%$ are presented here (for further details see supplementary material). 
For the elemental composition, the models employed greatly variable performance. $\mathrm{For} \mathrm{Fe}_{2} \mathrm{O}_{3}$ the best model performance, was reached by the LM algorithm $\left(R^{2} 0.441\right)$ by $G+S+C$ (Table 6), while the worst performance was by the Cubist $\left(R^{2}\right.$ 350 0.282) by $\mathrm{G}+\mathrm{C}$ (Table 4). With respect to $\mathrm{TiO}_{2}$, the best model performance was by Cubist algorithm $\left(\mathrm{R}^{2} 0.358\right)$ by $\mathrm{G}+\mathrm{S}$ $+\mathrm{C}$ (Table 6) and the worst was $\mathrm{RF}\left(\mathrm{R}^{2}\right.$ 0.248) by $\mathrm{G}+\mathrm{C}$ (Table 4). For $\mathrm{SiO}_{2}$, the best model performance was the Cubist algorithm ( $\mathrm{R}^{2}$ 0.250) by $\mathrm{S}+\mathrm{C}$ (Table 3) and the worst was the LM (R2 0.178) by G + C (Table 4). The importance of covariates in predicting $\mathrm{Fe}_{2} \mathrm{O}_{3}$ by $\mathrm{LM}$ in $\mathrm{G}+\mathrm{S}+\mathrm{C}$, demonstrated that magnetic susceptibility $(\kappa)$, standardized height and DEM were the most important variables, contributing 100\%, 65\%, 55\%, respectively (Fig. 6). For $\mathrm{Fe}_{2} \mathrm{O}_{3}$ predicted by the 355 Cubist algorithm by $\mathrm{G}+\mathrm{C}$, the most important covariates were standardized height, parent material, ECa and DEM (100\%) (Fig. 7). For $\mathrm{TiO}_{2}$ prediction by the Cubist algorithm by $\mathrm{G}+\mathrm{S}+\mathrm{C}$ the most important covariate was magnetic susceptibility (к) (100\%) (Fig. 6), while for the RF algorithm by G + C were parent material (100\%) and ECa (75\%) (Fig. 7). In relation to $\mathrm{SiO}_{2}$ prediction by the Cubist by $\mathrm{S}+\mathrm{C}$, the most important covariates were standardized height, mid-slope position magnetic susceptibility $(\kappa)$ and DEM (100\%) (Fig. 5), while $\mathrm{SiO} 2$ predicted by the LM algorithm by $\mathrm{G}+\mathrm{C}$ were DEM and standardized height (100\% and 65\%, respectively) to mean accuracy (Fig. 7). 
https://doi.org/10.5194/gmd-2021-153

Preprint. Discussion started: 16 July 2021

(c) Author(s) 2021. CC BY 4.0 License.
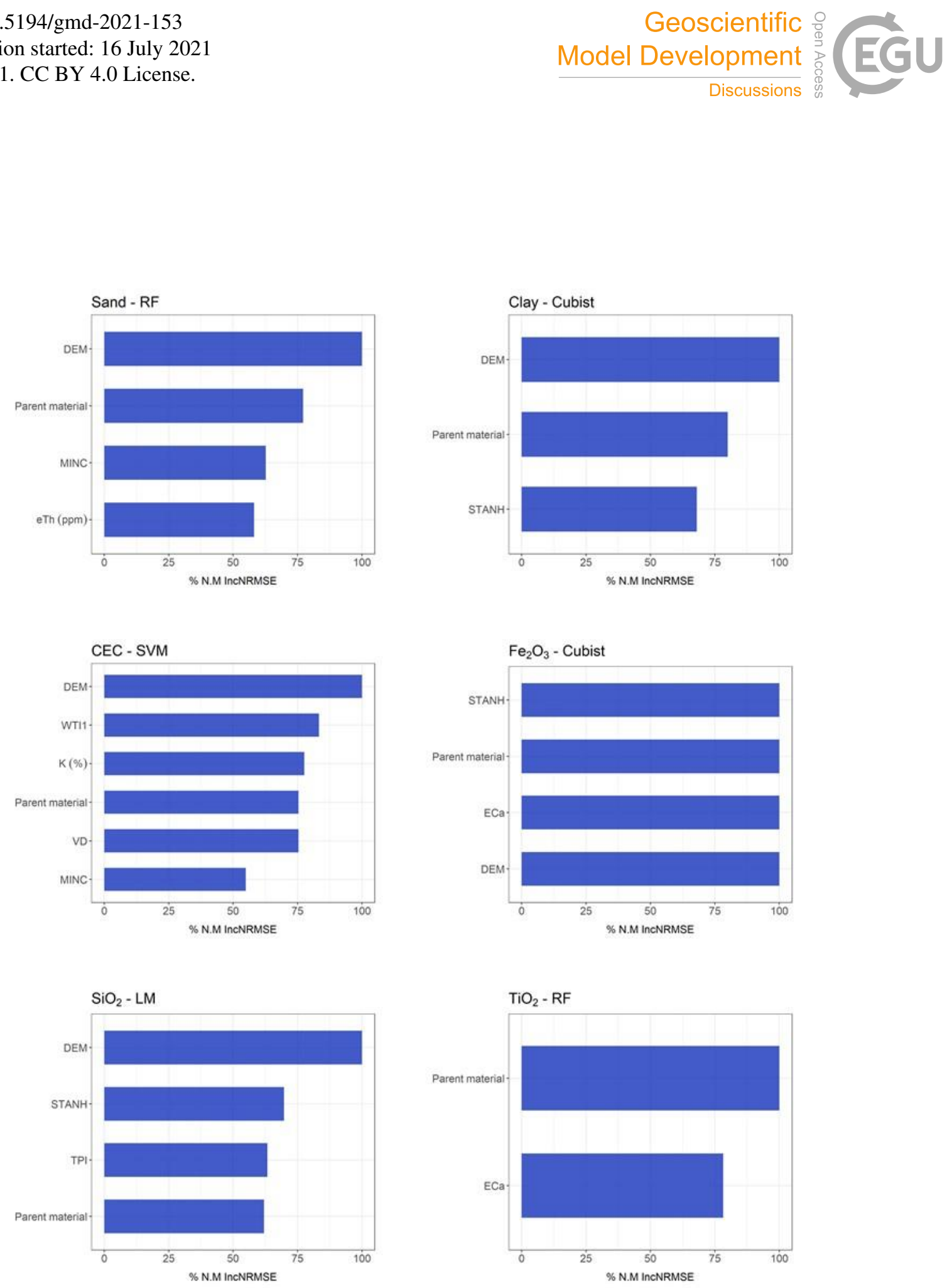

Figure 7. Variable Importance for Gamma-ray spectrometer + Conductivimeter sensors (only variables that contributed more than $50 \%$ are presented here (for further details see supplementary material). 
365 In relation to CEC, the LM algorithm was the best model $\left(\mathrm{R}^{2} 0.317\right)$ by $\mathrm{G}+\mathrm{S}+\mathrm{C}$ (Table 6$)$ and the worst was the SVM algorithm $\left(\mathrm{R}^{2}\right.$ 0.223) by $\mathrm{S}+\mathrm{C}$ (Table 3). The most important covariate for prediction of CEC by LM algorithm by $\mathrm{G}+\mathrm{S}+$ $\mathrm{C}$ and by $\mathrm{S}+\mathrm{C}$ was magnetic susceptibility $(\kappa)(100 \%)$ (Fig. 6 and 5).

Overall, the best combination of geophysical sensors, which allowed the best model performance for different algorithms in the prediction of soil attributes, was Gamma-ray spectrometer + Susceptibilimeter $(\mathrm{G}+\mathrm{S})$ (Table 5).

Table 5. Models' performance for combined use of gamma-ray spectrometer and susceptibilimeter, for all soil attributes, based on R², RMSE, MAE and NULL_RMSE

\begin{tabular}{|c|c|c|c|c|c|c|c|c|c|}
\hline \multicolumn{10}{|c|}{ Gamma-ray spectrometer + Susceptibilimeter } \\
\hline & & Clay & Sand & $\mathrm{Fe}_{2} \mathrm{O}_{3}$ & $\mathrm{TiO}_{2}$ & $\mathrm{SiO}_{2}$ & CEC & BS & OM \\
\hline \multirow{4}{*}{$\mathbf{R}^{2}$} & Random Forest & 0.465 & 0.422 & 0.36 & 0.308 & 0.159 & 0.147 & 0.169 & 0.046 \\
\hline & Cubist & 0.441 & 0.152 & 0.426 & 0.282 & 0.207 & 0.152 & 0.082 & 0.033 \\
\hline & SVM & 0.494 & 0.367 & 0.096 & 0.284 & 0.169 & 0.296 & 0.112 & 0.028 \\
\hline & LM & 0.366 & 0.233 & 0.47 & 0.328 & 0.167 & 0.303 & 0.002 & 0.034 \\
\hline \multirow{5}{*}{$\mathrm{RMSE}^{2}$} & Random Forest & 127.149 & 165.624 & 53.418 & 10.724 & 40.898 & 41.902 & 19.294 & 7.800 \\
\hline & Cubist & 132.977 & 244.635 & 52.737 & 11.37 & 40.244 & 44.296 & 21.318 & 7.842 \\
\hline & SVM & 123.84 & 175.35 & 67.759 & 10.846 & 42.207 & 38.723 & 20.856 & 7.81 \\
\hline & LM & 148.11 & 202.104 & 48.513 & 10.659 & 42.993 & 37.645 & 1024.32 & 8.131 \\
\hline & NULL_RMSE & 140.885 & 176.521 & 53.341 & 10.239 & 35.450 & 36.139 & 17.142 & 6.158 \\
\hline \multirow{5}{*}{ MAE } & Random Forest & 102.229 & 134.525 & 33.284 & 6.548 & 30.394 & 28.977 & 15.597 & 5.805 \\
\hline & Cubist & 105.123 & 168.957 & 32.411 & 6.573 & 29.691 & 30.945 & 17.321 & 5.836 \\
\hline & SVM & 97.173 & 140.318 & 42.282 & 6.447 & 30.396 & 25.376 & 16.96 & 5.966 \\
\hline & LM & 117.097 & 166.083 & 33.124 & 7.049 & 32.951 & 25.815 & 137.422 & 6.262 \\
\hline & NULL_RMSE & 119.751 & 153.803 & 41.578 & 8.074 & 29.534 & 27.187 & 14.425 & 4.813 \\
\hline
\end{tabular}

375 Clay and sand content in g.kg ${ }^{-1} ; \mathrm{Fe}_{2} \mathrm{O}_{3}, \mathrm{TiO}_{2}$ and $\mathrm{SiO}_{2}$ in $\mathrm{g} . \mathrm{kg}^{-1} \mathrm{CEC}$ in $\mathrm{mmol}_{\mathrm{c}} \mathrm{dm}^{-3}$; Abbreviations: CEC: Cation Exchange Capacity; OM g.dm ${ }^{-3}$; BS: mmolc $\mathrm{dm}^{-3}$. 
https://doi.org/10.5194/gmd-2021-153

Preprint. Discussion started: 16 July 2021

(c) Author(s) 2021. CC BY 4.0 License.

Table 6. Models' performance for all combined use of geophysical sensors, for all soil attributes, based on $\mathrm{R}^{2}$, RMSE, MAE

\begin{tabular}{|c|c|c|c|c|c|c|c|c|c|}
\hline \multicolumn{10}{|c|}{ Combined use of the three geophysical sensors } \\
\hline & & Clay & Sand & $\mathrm{Fe}_{2} \mathrm{O}_{3}$ & $\mathrm{TiO}_{2}$ & $\mathrm{SiO}_{2}$ & CEC & BS & OM \\
\hline \multirow{4}{*}{$\mathbf{R}^{2}$} & Random Forest & 0.356 & 0.318 & 0.281 & 0.322 & 0.162 & 0.171 & 0.122 & 0.003 \\
\hline & Cubist & 0.387 & 0.322 & 0.406 & 0.358 & 0.212 & 0.266 & 0.097 & 0.073 \\
\hline & SVM & 0.331 & 0.278 & 0.309 & 0.267 & 0.21 & 0.246 & 0.107 & 0.002 \\
\hline & LM & 0.258 & 0.129 & 0.441 & 0.252 & 0.125 & 0.317 & 0.002 & 0.047 \\
\hline \multirow{5}{*}{$\mathrm{RMSE}^{2}$} & Random Forest & 139.61 & 180.339 & 57.225 & 10.472 & 40.642 & 41.451 & 19.951 & 8.234 \\
\hline & Cubist & 139.41 & 188.745 & 52.66 & 10.547 & 40.534 & 39.226 & 21.749 & 7.569 \\
\hline & SVM & 144.532 & 189.768 & 57.589 & 11.053 & 40.355 & 39.815 & 21.178 & 8.134 \\
\hline & LM & 160.894 & 256.078 & 50.038 & 11.499 & 43.949 & 37.134 & 1045.896 & 7.752 \\
\hline & NULL_RMSE & 140.885 & 176.521 & 53.341 & 10.239 & 35.450 & 36.139 & 17.142 & 6.158 \\
\hline \multirow{5}{*}{ MAE } & Random Forest & 112.126 & 143.98 & 35.597 & 6.414 & 30.215 & 29.014 & 15.887 & 6.223 \\
\hline & Cubist & 108.346 & 145.661 & 32.751 & 6.541 & 30.197 & 27.169 & 17.694 & 5.854 \\
\hline & SVM & 117.645 & 145.187 & 35.387 & 6.7 & 30.001 & 26.201 & 17.025 & 5.945 \\
\hline & LM & 120.83 & 198.059 & 34.724 & 8.102 & 33.649 & 25.273 & 140.716 & 5.798 \\
\hline & NULL_RMSE & 119.751 & 153.803 & 41.578 & 8.074 & 29.534 & 27.187 & 14.425 & 4.813 \\
\hline
\end{tabular}

Clay and sand content in g.kg ${ }^{-1} ; \mathrm{Fe}_{2} \mathrm{O}_{3}, \mathrm{TiO}_{2}$ and $\mathrm{SiO}_{2}$ in g.kg- ${ }^{-1} \mathrm{CEC}$ in $\mathrm{mmol}_{\mathrm{c}} \mathrm{dm}^{-3} ;$ Abbreviations: CEC: Cation Exchange

Capacity; OM g.dm ${ }^{-3}$; BS: mmolc $\mathrm{dm}^{-3}$.

For soil texture, the SVM and RF algorithms, showed the best performance for clay $\left(R^{2} 0.494\right)$ and sand $\left(R^{2} 0.422\right)$, respectively, by $\mathrm{G}+\mathrm{S}$, with the highest $\mathrm{R}^{2}$ and lowest RMSE and MAE, simultaneously (Table 5). The importance of covariates in predicting soil texture by the SVM (for clay) and the RF (for sand) demonstrated that, magnetic susceptibility (к) was the most important covariate (100\%). In addition, parent material contributed 60\% for clay prediction and DEM 60\% for sand prediction (Fig. 8).

The LM algorithm presented the best performance for $\mathrm{Fe}_{2} \mathrm{O}_{3}\left(\mathrm{R}^{2}\right.$ 0.470) and $\mathrm{TiO}_{2}\left(\mathrm{R}^{2} 0.328\right)$, by $\mathrm{G}+\mathrm{S}$, while for $\mathrm{SiO}_{2}$ was the Cubist algorithm $\left(\mathrm{R}^{2}\right.$ 0.207), also by $\mathrm{G}+\mathrm{S}$ (Table 5). The most important covariates for $\mathrm{Fe}_{2} \mathrm{O}_{3}$ and $\mathrm{TiO}_{2}$ prediction by LM by $\mathrm{G}+\mathrm{S}$ were magnetic susceptibility $(\kappa)$ and standardized height (100\% and 60\%, respectively for both) (Fig. 8). For

$400 \mathrm{SiO} 2$ prediction by the Cubist by $\mathrm{G}+\mathrm{S}$, the most important covariates were mid-slope position and magnetic susceptibility (к) (100\% for both) (Fig. 8).

For CEC, the best model performance was the LM algorithm $\left(\mathrm{R}^{2} 0.303\right)$ by $\mathrm{G}+\mathrm{S}$ (Table $\left.\mathbf{5}\right)$. In this case, the covariates that most contributed to model prediction were magnetic susceptibility (א) (100\%) and DEM (60\%) (Fig. 8). 
https://doi.org/10.5194/gmd-2021-153

Preprint. Discussion started: 16 July 2021

(c) Author(s) 2021. CC BY 4.0 License.
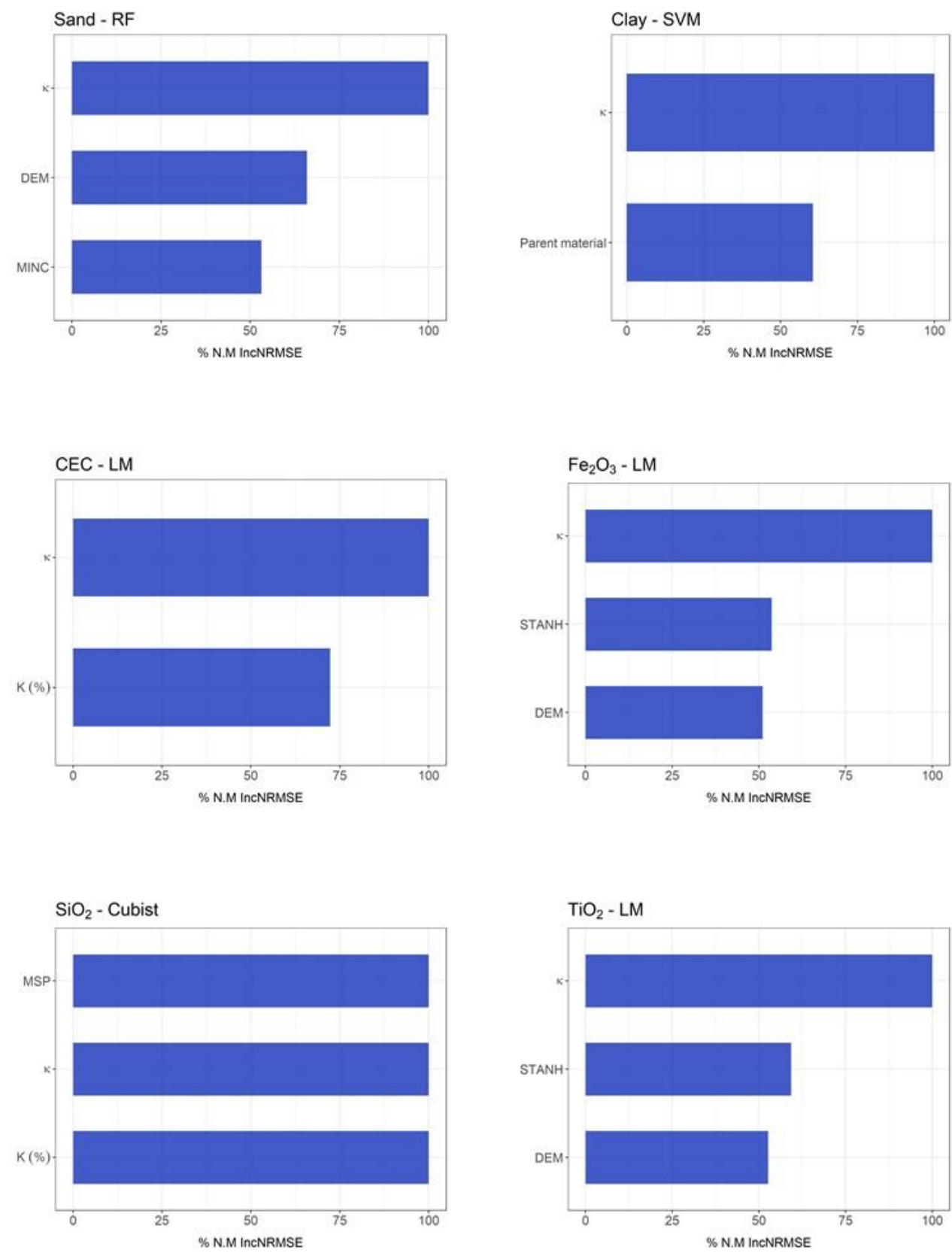

405 Figure 8. Variable Importance for Gamma-ray spectrometer + Susceptibilimeter sensors (only variables that contributed more than $50 \%$ are presented here (for further details see supplementary material). 


\section{Discussion}

\subsection{Geophysical sensors combinations, models performance and uncertainty}

410 The methodological approach optimized the prediction of soil variables by applying different geophysical sensors combination, parent material and terrain attributes for selecting covariates and models, as well as for assessing prediction uncertainty.

In general, without the use of geophysical sensors the poorest results were obtained, in terms of $\mathrm{R}^{2}$, RMSE and MAE, for all the prediction algorithms used for modeling soil attributes (Table 2). These results are consistent with Frihy et al., (1995)

415 who also compared combined use and the non-use of sensors to model geochemical attributes of soil by the Cubist algorithm and obtained the worst result without using the sensors. The worst performance of the models can be attributed to a very complex interaction between soil forming factors and processes, determining soil attributes (Jenny, 1994).

The moderate performance of the models can be attributed to the different combinations of the geophysical sensors pairwise, and the different data presented by the sensors contributed in different ways to the modelling process. In this concern, O'Rourke et al., (2016) also demonstrated a moderate performance of the models ( $\mathrm{R}^{2}$ ranging from 0.21 to 0.94 ) when using data from the VisNir and, with $\mathrm{R}^{2}$ ranging from 0.61 to 0.94 , when using XRF sensor, to model soil attributes. The explanation can be related to correlations of different data provided by different sensors and, their relation with soil attributes.

The best combination of geophysical sensors was Gamma-ray spectrometer + Susceptibilimeter $(\mathrm{G}+\mathrm{S})$, with the highest values of $\mathrm{R}^{2}$ and lowest values of RMSE and MAE, concomitantly, among all combinations of geophysical sensors and algorithms used in the modeling processes (Table 5). Probably the explanation lies in the fact that the gamma-ray spectrometer and susceptibilimeter are more closely associated with pedogenesis, pedogeomorphology and soil attributes, as recently demonstrated by Mello et al. (2020); Mello et al. (2021), who modeled soil attributes such as texture, $\mathrm{Fe}_{2} \mathrm{O}_{3}, \mathrm{TiO}_{2}$, $\mathrm{SiO}_{2}$ and $\mathrm{CEC}$ in relation to Thorium, Uranium and Potassium $\left(\mathrm{K}^{40}\right)$ levels and magnetic susceptibility.

430 In general, the Cubist algorithm was the best model for clay and sand content prediction, (Table 7). Similar results were found by Greve and Malone, (2013); Ballabio et al., (2016); Nawar et al., (2016) and Silva, (2019) who used the Cubist and Earth algorithm to predict soil texture using different data source (3D imagery, Land Use and Cover Area frame Statistical survey and reflectance spectroscopy), reaching satisfactory performance. In all of these models the $\mathrm{R}^{2}$ was not greater than 0.5 in all cases. The probable explanation is the small variation or limited distribution of the data set, which caused a poor prediction in the modeling. Zhang and Hartemink, (2020), states that textural classes with fewer samples presented more unstable prediction performances than those with more samples, which agree with our results. 
Table 7. Number of times that each model achieved the best performance for each soil attribute

\begin{tabular}{ccccc}
\hline \multirow{2}{*}{ Soil attributes } & \multicolumn{4}{c}{$\boldsymbol{R}^{\mathbf{2}}$} \\
\cline { 2 - 5 } & Random Forest & Cubist & S V M & LM \\
\hline Clay & 2 & 3 & 2 & \\
Sand & & 3 & & \\
$\mathrm{Fe}_{2} \mathrm{O}_{3}$ & 1 & 2 & 1 & 2 \\
$\mathrm{TiO}_{2}$ & & 3 & & 2 \\
$\mathrm{SiO}_{2}$ & & & 3 & 2 \\
$\mathrm{CEC}$ & & &
\end{tabular}

Clay and sand content in g.kg ${ }^{-1} ; \mathrm{Fe}_{2} \mathrm{O}_{3}, \mathrm{TiO}_{2}$ and $\mathrm{SiO}_{2}$ in g.kg ${ }^{-1} \mathrm{CEC}$ in $\mathrm{mmol}_{\mathrm{c}} \mathrm{dm}^{-3}$; Abbreviations: CEC: Cation Exchange Capacity

445 The better model performance for elemental composition $\left(\mathrm{Fe}_{2} \mathrm{O}_{3}, \mathrm{TiO}_{2}\right.$ and $\left.\mathrm{SiO}_{2}\right)$ was the Cubist (Table 7) with a $\mathrm{R}^{2}(0.2-$ 0.47). This is contrasting with results obtained by Henrique et al., (2018), who showed that the best models for predicting soil mineralogy $\mathrm{Fe}_{2} \mathrm{O}_{3}$ and $\mathrm{TiO}_{2}\left(\mathrm{R}^{2} 0.89\right.$ and 0.96 , respectively) and $\mathrm{RF}$ only for $\mathrm{Fe}_{2} \mathrm{O}_{3}\left(\mathrm{R}^{2} 0.95\right)$ by pXRF was the simple linear regression. The $\mathrm{R}^{2}$ variation in our results for $\mathrm{G}+\mathrm{S}$ combination is probably related to low correlation with parent material and consequently with soil mineralogy, or to the low representativeness by the limited number of samples, and high soil variability (Fiorio, 2013). However, it is important to highlight that in-situ have many intrinsic environmental influences that can interfere in modelling processes. It can justify the low $\mathrm{R}^{2}$ values obtained. For soil mineralogical attributes predicted by machine learning algorithms, results can be classified as satisfactory from 0.2 to 0.5 , as for preliminary evaluation, since these values present more informative results (Beckett, 1971; Dobos, 2003; Malone et al., 2009). According to Nanni and Demattê (2006), the $\mathrm{R}^{2}$ may be explained by standardized laboratory conditions during their determination, which have less environmental interference compared with direct field methods.

For CEC the best model performance was SVM $\left(\mathrm{R}^{2}\right.$ 0.296) (Table 5). This results is corroborated by Liao et al., (2014), who compared the models performance of multiple stepwise regression, artificial neural network models and SVM for CEC prediction, and attributed their results to a nonlinear relationship between CEC and soil physicochemical properties. In addition, other study (Jafarzadeh et al., 2016) demonstrated that, despite of the ability of SVM to predict CEC in acceptable limits, there is a poor performance in extrapolating the maximum and minimum values of CEC data. Despite this, uncertainties estimated for SVM predictions may not be associated with an incorrect classification. As pointed out by Cracknell and Reading, (2013).

Even for the best combination of sensors $(G+S)$ and the overall models' performance, the $\mathrm{R}^{2}$ values were not greater than 0.5 (Table 5). Models generated by field data, without sample preparation, $R^{2}$ values varying between $0.20-0.50$ can be considered satisfactory and reliable results (Dobos, 2003; Malone et al., 2009). In our study, low $\mathrm{R}^{2}$ values can be related to 
https://doi.org/10.5194/gmd-2021-153

Preprint. Discussion started: 16 July 2021

(c) Author(s) 2021. CC BY 4.0 License.

the limited number of collecting points or field distribution, which does not represent the spatial variation of soil attributes, in agreement with Johnston et al. (1997) and Lesch et al. (1992), who evaluated soil salinity.

The best results for predictors of soil attributes through geophysical data, have the lowest values when compared to the values of NULL_RMSE and NULL_MAE. This demonstrates that the use of machine learning models has lesser errors than the use of means values for the entire area (Table 5) so that it shows better performance and accuracy.

There are little studies using NULL_RMSE and NULL_MAE as parameters for model evaluation and decision making. These values can be used to evaluate the performance of the models. Algorithms that have RMSE and MAE values greater than the values found in the NULL method, perform less than the use of the mean value for the entire area. The values of NULL_RMSE and NULL_MAE can be used concurrently with kriging to evaluate the performance of the models. However,

475 we could not apply ordinary kriging in our case because the most predictors did not have spatial dependence (pure nugget effect), as demonstrated by Mello et al., (2021).

\subsubsection{Variables importance, models performance and pedogeomorphology}

In general, for all geophysical sensor combinations, the majority of terrain attributes used did influence significatively sand and clay content prediction (Fig. 4, 5, 6 and 8). However, in most cases parent material and magnetic susceptibility strongly influences clay content prediction, except for G + C (Fig. 7). Ließ et al. (2012) found that the best performance was by the RF model with altitude and overland flow distance strongly affecting the model performance. According to Bauer (2010), the greater relation sand/clay ratio upslope is explained by selective transport of fine material downslope, whereas in the present study, clay content increased by the influence of parent material (diabase) as demonstrated by Mello et al. (2020).

485 The magnetic susceptibility $(\kappa)$, followed by DEM and parent material were key the variables that contributed to sand and clay content prediction by RF and SVM, respectively for G + S (Fig. 8). Siqueira et al. (2010) and Mello et al. (2020) found a positive correlation between soil magnetic susceptibility and clay content and a negative correlation between magnetic susceptibility and sand content. In fact, the mineralogical composition of parent material strongly affects soil magnetic susceptibility (Ayoubi et al., 2018), mainly in tropical soils under top of basalt spills (Da Costa et al., 1999), where our study was undertaken.

In general, for $\mathrm{Fe}_{2} \mathrm{O}_{3}$ and $\mathrm{TiO}_{2}$ the most important variables were parent material, magnetic susceptibility and DEM, which in most cases contributed 100\% (Fig. 4, 5, 6, 7 and 8). In fact, the mineralogical composition of the parent material and pedoenvironmental conditions strongly influences the amount of Fe/Ti oxides in soils (Schwertmann and Taylor, 1989; Kämpf and Curi, 2000; Bigham et al., 2002), and faster redistributed by erosion downslope (Mello et al., 2020). Also, the mineralogical composition of parent material (Mullins, 1977; Ayoubi et al., 2018) and landform evolution (Blundell et al., 2009; Sarmast et al., 2017) controls the magnetic susceptibility of soil. Since the sensors used record the surface response and topography effect, it is expected that the most important variables indicated by the models would be related to surface processes. For the best combination of sensors $(\mathrm{G}+\mathrm{S})$, magnetic susceptibility and standardized height were more important variables in the prediction of $\mathrm{Fe}_{2} \mathrm{O}_{3}(100 \%)$ and $\mathrm{TiO}_{2}(55 \%)$ contents (Fig. 8), corroborating the expected surface processes 
and materials in the magnetic susceptibility of the soil (Shenggao, 2000; Damaceno et al., 2017) and the relief in the distribution of these materials (De Jong et al., 2000).

For $\mathrm{SiO}_{2}$, the most important variable was DEM which in most of cases contributed 100\% (Fig. 4, 5, 6 and 7). The levels of $\mathrm{SiO}_{2}$ in soil is directly related to the nature of parent material and erosion processes at different topographic positions at the landscape (Bockheim et al., 2014; Breemen and Buurman, 2003). This can explain the greater contribution of the DEM in

505 the prediction models. For the best sensor combination $(G+S)$, the variable that most contributed was mid-slope position, which also is related to topographic features.

For CEC, the variables DEM and magnetic susceptibility were the most important, contributing 100\% in most of cases (Fig. 4, 5, 6, 7 and 8). This can be explained by the high correlation between magnetic susceptibility and clay content, and that with CEC (Siqueira et al., 2010; de Souza Bahia et al., 2017; Mello et al., 2020). They vary with parent material and surface

510 geomorphic processes, concentrating the rich ferrimagnetic minerals (Frihy et al., 1995; Mello et al., 2020).

Considering that the gamma spectrometer sensor is composed of three channels (eU, eTh and $\mathrm{K}^{40}$ ), we can call it "three sensors". Thus, considering the combination of sensors used, it is possible to create a performance graph of the modeling by the number of sensors used through learning curves (Fig. 9). A learning curve shows a measure of predictive performance of a given domain as a function of some measure of varying amounts of learning effort (Perlich, 2010). In our case, the varying 515 amounts were the number of sensors: non-use of geophysical sensors (0 sensors), $\mathrm{S}+\mathrm{C}$ ( 2 sensors), $\mathrm{G}+\mathrm{S}$ (4 sensors) and $\mathrm{S}$ $+\mathrm{G}+\mathrm{C}$ ( 5 sensors). In this analysis, the combination of $\mathrm{G}+\mathrm{C}$ sensors will not be used because they present the same number of $\mathrm{G}+\mathrm{S}$ sensors (4 sensors). However, the combination $\mathrm{G}+\mathrm{C}$ presented lower results than those for $\mathrm{G}+\mathrm{S}$.

The results show that for 5 soil properties (clay, sand, $\mathrm{CEC}, \mathrm{Fe}_{2} \mathrm{O}_{3}$ and $\mathrm{SiO}_{3}$ ), the best results did not occur with a greater number of sensors, showing that increasing number of covariables can lead to lower performance (Fig. 9). This fact is 520 associated with the addition of a new sensor as a covariate that may be leading to conflicting information to the set of other sensors found, where the ECa may have presented conflicting values with the sensors generated by the gamma spectrometry channels, which generates a loss of performance when with sensor sets together. The application of the RFE importance selection method was able to amortize this, being a reliable method to reduce this effect. 

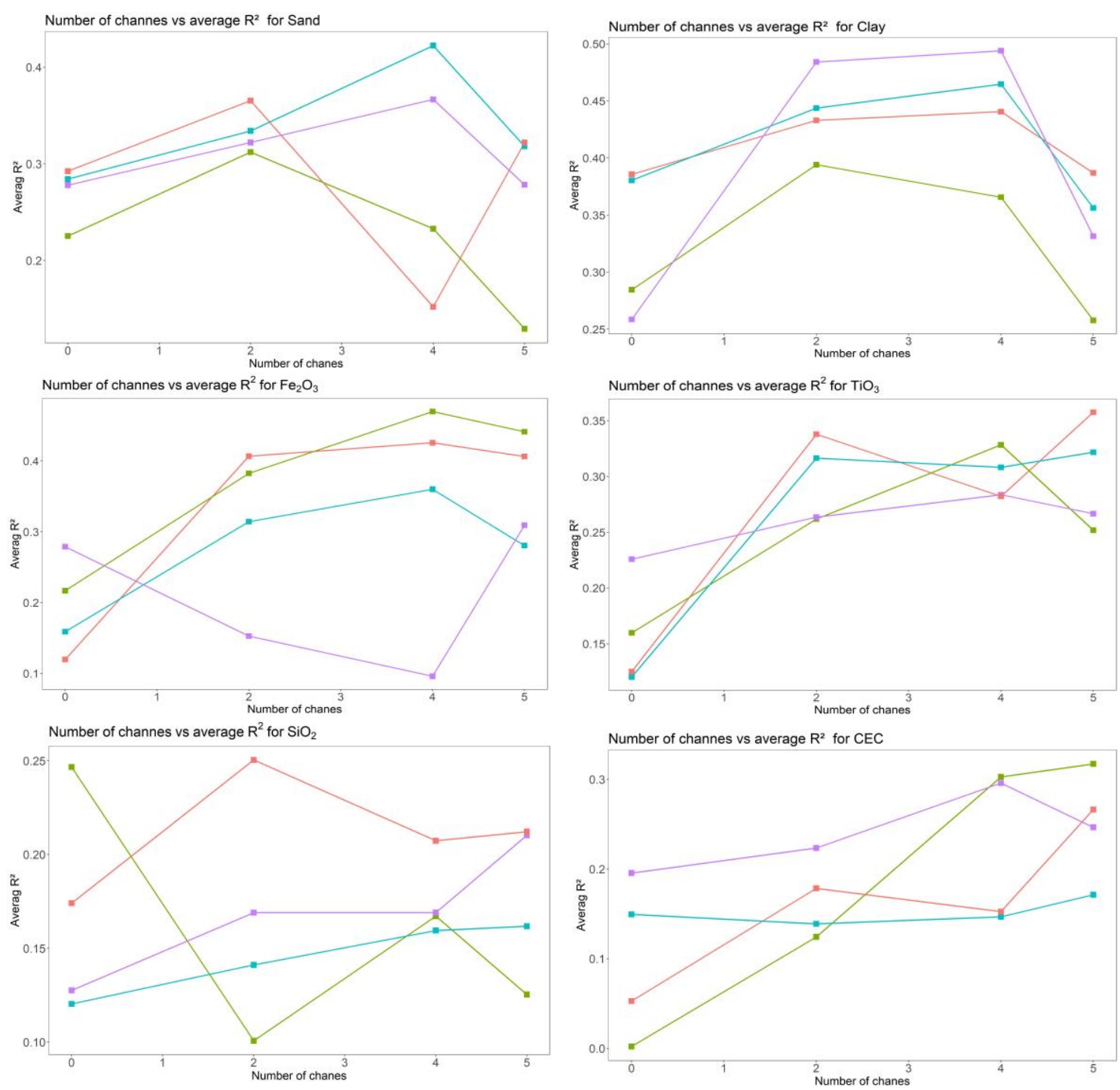

525 Figure 9. Learning curves calculated on the metric by which the parameters of the model were optimized and on the metric by which the model was evaluated and selected. The most common form of learning curves in the general field of machine learning shows predictive accuracy on the test examples as a function of the number of training examples (Perlich, 2010).

\subsubsection{General evaluation}

530 For this study, the independent RMQS data set was not large enough (75 sites). So, validation using 74 sites provided erratic and inconsistent results, mainly when compared different pedoenvironmental indicators, even considering that this dataset, in theory, provide "unbiased" estimates of forecast performance (Loiseau et al., 2020). Similarly, Lagacherie et al., (2019) showed that the location and number of samples used for independent assessment can significantly impact the value of these indicators. This indicates the greatest variations were observed for evaluation sets with less than 100 samples. 
535 Modeling soil attributes using relief and geophysical data presented promising results for geosciences studies and soil scientists. The use of several algorithms from different "families", the training and validation method also made the study more robust and more reliable. In addition, machine learning models allowed to define the importance of covariates, which are, sometimes, not possible use ordinary spatialization methods, such as kriging and the inverse square of distance.

The "nested leave-one-out validation" method was usefulness with small samples, being a potential tool to be used in

540 geosciences studies. However, still there is a poor knowledge in the academic community on the potential applicability of machine learning techniques.

\section{Conclusions}

It is possible to model soil attributes satisfactorily, with easily acquired input data (parent material + DEM) combined with

545 data set from different geophysical sensors. In addition, geophysical data from proximal sensors coupled with Cubist algorithms can provide accurate estimates for several soil attributes. This may assist soil survey programs to reduce the need for new soil samples and wet chemistry.

The combination of geophysical sensors with the best model performance (higher $\mathrm{R}^{2}$ and lower RMSE and MAE, concomitantly) for the prediction of soil attributes, was Gamma-ray spectrometer + Susceptibilimeter $(\mathrm{G}+\mathrm{S})$. The use of

550 three equipment in simultaneous did not optimize model's performance. On the other hand, the Non-use of geophysical sensors, presented the lower performance of soil attributes prediction by machine learning algorithms.

In general, the algorithms showed varying performances. In general, the Cubist was the best one for clay, sand, $\mathrm{Fe}_{2} \mathrm{O}_{3}, \mathrm{TiO}_{2}$, $\mathrm{SiO}_{2}$. For CEC the best performance was by SVM. The second-best algorithm performance was SVM for clay, RF for sand and $\mathrm{LM}$ for $\mathrm{Fe}_{2} \mathrm{O}_{3}, \mathrm{TiO}_{2}, \mathrm{SiO}_{2}$ and $\mathrm{CEC}$.

555 The prediction performance for most soil attributes showed $\mathrm{R}^{2}$ greater than 0.2 , considered satisfactory for machine learning algorithms applied to field data without expensive laboratory analysis, especially when compared with data from fieldwork with the use of remote sensing covariates. All soil attributes obtained superior performance considering an average value for the entire area.

The use of the null model methodology provided a way of comparing those generated by machine learning, when it

560 is not possible to use other methods. The use of four algorithms proved necessary since at least one of the soils attributes performed better in each of the tested algorithms.

The final model was more parsimonious with an ideal number of covariates with a three steps selection. This reduced the effect of overfitting by the use of a large number of covariates. Also, the nested leave-one-out validation methodology proved to be appropriate for small number of samples when compared to the hold-out validation and cross-validation.

565 The covariables that most contributed to the prediction of soil attributes (clay, sand, $\mathrm{Fe}_{2} \mathrm{O}_{3}, \mathrm{TiO}_{2}, \mathrm{SiO}_{2}$ and $\mathrm{CEC}$ ), in the most of algorithms used and sensors combinations were DEM, magnetic susceptibility, parent material and standardized height. 
For each study area, a conceptual pedogeomorphological and geophysical model must be created due to the complex interaction between environmental variables, pedogenesis and soil attributes. These factors affect geophysical variables which are detected and quantified by the sensors and will later serve as input data for the modeling processes.

570 The machine learning technique is a potential tool for modelling soil attributes with geophysical data, when only field data with proximal sensors are available. The combined use of gamma-ray spectrometer and susceptibilimeter, allowed for an optimization of the models.

\section{Declaration of non-availability of relevant model code for the manuscript}

575

$\bigotimes$ The authors declare that they have no code or data relevant to the paper.

$\bigotimes$ The authors declare that they have used basic R software packages, described in details in material

\section{Authors contribution}

Danilo César de Mello: conceived of the presented idea, carried out the experiment, developed the theoretical formalism, contributed to the design and implementation of the research, to the analysis of the results and to the writing of the manuscript. He provided critical feedback and helped shape the research, analysis and manuscript.

Gustavo Vieira Veloso: designed the model and the computational framework and analysed the data, planned and carried out the simulations, performed the analytic calculations and performed the numerical simulations, modelling processing, evaluate algorithms performance, variables importance and statistical analyses.

Marcos Guedes de Lana: contributed to the interpretation of the results, took the lead in writing the manuscript. Devised the project, the main conceptual ideas and proof outline. He worked out almost all of the technical details. All authors provided critical feedback and helped shape the research, analysis and manuscript.

Fellipe Alcantara de Oliveira Mello: contributed to the interpretation of the results, took the lead in writing the manuscript. All authors provided critical feedback and helped shape the research, analysis and manuscript.

Raul Roberto Poppiel: contributed to the interpretation of the results, took the lead in writing the manuscript. All authors provided critical feedback and helped shape the research, analysis and manuscript.

Diego Ribeiro Oquendo Cabrero: performed the analysis, drafted the manuscript and designed the figure. All authors provided critical feedback and helped shape the research, analysis and manuscript. 
Luis Augusto Di Loreto Di Raimo: performed the analysis, drafted the manuscript and designed the figure. All authors provided critical feedback and helped shape the research, analysis and manuscript.

605 Carlos Ernesto Gonçalves Reynaud Schaefer: Critical revision of the article. All authors discussed the results and commented on the manuscript. He contributed to the interpretation of the results and verified the analytical methods.

Elpídio Inácio Fernandes Filho: Critical revision of the article. He designed the model and the computational framework and analysed the data. He contributed to the interpretation of the results and verified the analytical methods. All authors discussed the results and commented on the manuscript.

Emilson Pereira Leite: Critical revision of the article. He contributed to the interpretation of the results and verified the analytical methods. All authors discussed the results and commented on the manuscript.

615 José Alexandre Melo Demattê: Provided de financial support, leadership of the group, critical revision of the article. He contributed to the interpretation of the results and verified the analytical methods. Encouraged the co-authors to investigate a specific aspect and supervised the findings of this work.

\section{Acknowledgements}

We would like to thank the National Council for Scientific and Technological Development (CNPq) for the first author scholarship (grant No. 134608/2015-1); the São Paulo Research Foundation (FAPESP) (grant No. 2014-22262-0) for providing essential resources to the Laboratory of Remote Sensing Applied to Soils from "Luiz de Queiroz" College of Agriculture (ESALQ/USP); the Geotechnologies in Soil Science group (GeoSS - website http://esalqgeocis.wixsite.com/english) and LabGeo - UFV - 'Post Graduation Program in Soil and Plant Nutrition PGSNP' of the Soil Department of Federal University of Viçosa, Brazil; Institute of Geosciences at Campinas State University, for the support.

\section{References}

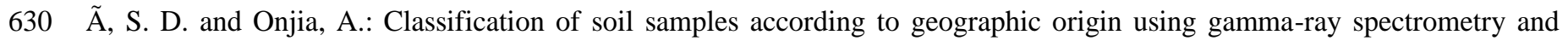
pattern recognition methods, , 65, 218-224, doi:10.1016/j.apradiso.2006.07.005, 2007.

Agbu, P. A., Fehrenbacher, D. J. and Jansen, I. J.: Soil property relationships with SPOT satellite digital data in east central 
https://doi.org/10.5194/gmd-2021-153

Preprint. Discussion started: 16 July 2021

(c) Author(s) 2021. CC BY 4.0 License.

(c) (i)

Illinois, Soil Sci. Soc. Am. J., 54(3), 807-812, 1990.

Alvares, C. A., Stape, J. L., Sentelhas, P. C., De Moraes Gonçalves, J. L. and Sparovek, G.: Köppen's climate classification

map for Brazil, Meteorol. Zeitschrift, 22(6), 711-728, doi:10.1127/0941-2948/2013/0507, 2013.

Amundson, R., Berhe, A. A., Hopmans, J. W., Olson, C., Sztein, A. E. and Sparks, D. L.: Soil and human security in the 21st century, Science (80-. )., 348(6235), 2015.

Arrouays, D., Grundy, M. G., Hartemink, A. E., Hempel, J. W., Heuvelink, G. B. M., Hong, S. Y., Lagacherie, P., Lelyk, G., McBratney, A. B., McKenzie, N. J., Mendonca-Santos, M. d. L., Minasny, B., Montanarella, L., Odeh, I. O. A., Sanchez, P.

A., Thompson, J. A. and Zhang, G.-L.: GlobalSoilMap: Toward a Fine-Resolution Global Grid of Soil Properties, in Advances in Agronomy 125, pp. 93-134., 2014.

Ayoubi, S., Abazari, P. and Zeraatpisheh, M.: Soil great groups discrimination using magnetic susceptibility technique in a semi-arid region, central Iran, Arab. J. Geosci., 11(20), doi:10.1007/s12517-018-3941-4, 2018.

Bai, W., Kong, L. and Guo, A.: Effects of physical properties on electrical conductivity of compacted lateritic soil, J. Rock

Mech. Geotech. Eng., 5(5), 406-411, doi:10.1016/j.jrmge.2013.07.003, 2013.

Ballabio, C., Panagos, P. and Monatanarella, L.: Mapping topsoil physical properties at European scale using the LUCAS database, Geoderma, 261, 110-123, doi:10.1016/j.geoderma.2015.07.006, 2016.

Barbuena, D., de Souza Filho, C. R., Leite, E. P., Miguel Jr, E., de Assis, R. R., Xavier, R. P., Ferreira, F. J. F. and Paes de Barros, A. J.: Airborne geophysical data analysis applied to geological interpretation in the Alta Floresta Gold Province, MT,

650 Rev. Bras. Geofísica, 2013.

Batty, M. and Torrens, P. M.: Modelling complexity: the limits to prediction, Cybergeo Eur. J. Geogr., 2001.

Bauer, F. C.: Water flow paths in soils of an undisturbed and landslide affected mature montane rainforest in South Ecuador, Bayreuth, Alem., 2010.

Bazaglia Filho, O., Rizzo, R., Lepsch, I. F., Prado, H. do, Gomes, F. H., Mazza, J. A. and Demattê, J. A. M.: Comparison

between detailed digital and conventional soil maps of an area with complex geology, Rev. Bras. Ciência do Solo, 37(5),

1136-1148, doi:10.1590/s0100-06832013000500003, 2013.

Beamish, D.: Gamma ray attenuation in the soils of Northern Ireland, with special reference to peat, J. Environ. Radioact., 115, 13-27, doi:10.1016/j.jenvrad.2012.05.031, 2013.

Beamish, D.: Relationships between gamma-ray attenuation and soils in SW England, Geoderma, 259-260, 174-186, 660 doi:10.1016/j.geoderma.2015.05.018, 2015.

Beckett, P. H. T.: Soil variability: a review, Soils Fertil., 34(1), 1-15, 1971.

Bigham, J. M., Fitzpatrick, R. W. and Schulze, D. G.: Iron oxides, Soil Mineral. with Environ. Appl., 7, 323-366, 2002.

Blundell, A., Dearing, J. A., Boyle, J. F. and Hannam, J. A.: Controlling factors for the spatial variability of soil magnetic susceptibility across England and Wales, Earth-Science Rev., 95(3-4), 158-188, doi:10.1016/j.earscirev.2009.05.001, 2009.

665 Bockheim, J. G., Gennadiyev, A. N., Hartemink, A. E. and Brevik, E. C.: Soil-forming factors and Soil Taxonomy, Geoderma, 226-227(1), 231-237, doi:10.1016/j.geoderma.2014.02.016, 2014. 
https://doi.org/10.5194/gmd-2021-153

Preprint. Discussion started: 16 July 2021

(c) Author(s) 2021. CC BY 4.0 License.

Breemen, Nico and Buurman, P.: Soil Formation, 2 nd., Laboratory of Soil Science and Geology, New YorkK, Boston, Dordrecht, London, Moscow., 2003.

Brungard, C. W., Boettinger, J. L., Duniway, M. C., Wills, S. A. and Edwards, T. C.: Geoderma Machine learning for predicting soil classes in three semi-arid landscapes, Geoderma, 239-240, 68-83, doi:10.1016/j.geoderma.2014.09.019, 2015.

Camargo, O.A.; Moniz, A.C.; Jorge, J.A. \& Valadares, J. M. A. S.: Métodos de análise química, mineralógica e física de solos do Instituto Agronômico do estado de São Paulo, Bol. técnico, 106, 94, 1986.

Camargo, L. A., Marques Júnior, J., Pereira, G. T. and Bahia, A. S. R. de S.: Clay mineralogy and magnetic susceptibility of Oxisols in geomorphic surfaces, Sci. Agric., 71(3), 244-256, doi:10.1590/S0103-90162014000300010, 2014.

Cardoso, R. and Dias, A. S.: Study of the electrical resistivity of compacted kaolin based on water potential, Eng. Geol., 226(January), 1-11, doi:10.1016/j.enggeo.2017.04.007, 2017.

César de Mello, D., Demattê, J. A. M., Silvero, N. E. Q., Di Raimo, L. A. D. L., Poppiel, R. R., Mello, F. A. O., Souza, A. B., Safanelli, J. L., Resende, M. E. B. and Rizzo, R.: Soil magnetic susceptibility and its relationship with naturally occurring processes and soil attributes in pedosphere, in a tropical environment, Geoderma, 372, doi:10.1016/j.geoderma.2020.114364, 2020.

Clevers, J. G. P. W., Van Der Heijden, G. W. A. M., Verzakov, S. and Schaepman, M. E.: Estimating grassland biomass using SVM band shaving of hyperspectral data, Photogramm. Eng. Remote Sensing, 73(10), 1141-1148, doi:10.14358/PERS.73.10.1141, 2007.

685 Correia, M. G., Leite, E. P. and de Souza Filho, C. R.: Comparação de métodos de estimativa de profundidades de fontes magnéticas utilizando dados aeromagnéticos da província mineral de Carajás, Pará, Brazilian J. Geophys., 28(3), 411-426, 2010.

Corwin, D. L., Lesch, S. M., Shouse, P. J., Soppe, R. and Ayars, J. E.: Identifying Soil Properties that Influence Cotton Yield Using Soil Sampling Directed by Apparent Soil Electrical Conductivity, , (1995), 352-364, 2003.

690 Da Costa, A. C. S., Bigham, J. M., Rhoton, F. E. and Traina, S. J.: Quantification and characterization of maghemite in soils derived from volcanic rocks in southern Brazil, Clays Clay Miner., 47(4), 466-473, doi:10.1346/CCMN.1999.0470408, 1999.

Cracknell, M. J. and Reading, A. M.: The upside of uncertainty: Identification of lithology contact zones from airborne geophysics and satellite data using random forests and support vector machines, Geophysics, 78(3), WB113-WB126, doi:10.1190/GEO2012-0411.1, 2013.

Damaceno, J. G., de Castro, D. L., Valcácio, S. N. and Souza, Z. S.: Magnetic and gravity modeling of a Paleogene diabase plug in Northeast Brazil, J. Appl. Geophys., 136, 219-230, doi:10.1016/j.jappgeo.2016.11.006, 2017.

Darst, B. F., Malecki, K. C. and Engelman, C. D.: Using recursive feature elimination in random forest to account for correlated variables in high dimensional data, BMC Genet., 19(1), 65, 2018.

Demattê, J. A. M., Galdos, M. V, Guimarães, R. V, Genú, A. M., Nanni, M. R. and Zullo Jr, J.: Quantification of tropical 
https://doi.org/10.5194/gmd-2021-153

Preprint. Discussion started: 16 July 2021

(c) Author(s) 2021. CC BY 4.0 License.

soil attributes from ETM+/LANDSAT-7 data, Int. J. Remote Sens., 28(17), 3813-3829, 2007.

Demattê, J. A. M., Horák-Terra, I., Beirigo, R. M., Terra, F. da S., Marques, K. P. P., Fongaro, C. T., Silva, A. C. and Vidal-

Torrado, P.: Genesis and properties of wetland soils by VIS-NIR-SWIR as a technique for environmental monitoring, J. Environ. Manage., 197, 50-62, doi:10.1016/j.jenvman.2017.03.014, 2017.

Demattê, J. A. M., Dotto, A. C., Paiva, A. F. S., Sato, M. V., Dalmolin, R. S. D., de Araújo, M. do S. B., da Silva, E. B., Nanni, M. R., ten Caten, A., Noronha, N. C., Lacerda, M. P. C., de Araújo Filho, J. C., Rizzo, R., Bellinaso, H., Francelino, M. R., Schaefer, C. E. G. R., Vicente, L. E., dos Santos, U. J., de Sá Barretto Sampaio, E. V., Menezes, R. S. C., de Souza, J. J. L. L., Abrahão, W. A. P., Coelho, R. M., Grego, C. R., Lani, J. L., Fernandes, A. R., Gonçalves, D. A. M., Silva, S. H. G., de Menezes, M. D., Curi, N., Couto, E. G., dos Anjos, L. H. C., Ceddia, M. B., Pinheiro, É. F. M., Grunwald, S., Vasques, G. M., Marques Júnior, J., da Silva, A. J., Barreto, M. C. d. V., Nóbrega, G. N., da Silva, M. Z., de Souza, S. F., Valladares, G. S., Viana, J. H. M., da Silva Terra, F., Horák-Terra, I., Fiorio, P. R., da Silva, R. C., Frade Júnior, E. F., Lima, R. H. C., Alba, J. M. F., de Souza Junior, V. S., Brefin, M. D. L. M. S., Ruivo, M. D. L. P., Ferreira, T. O., Brait, M. A., Caetano, N. R., Bringhenti, I., de Sousa Mendes, W., Safanelli, J. L., Guimarães, C. C. B., Poppiel, R. R., e Souza, A. B., Quesada, C. A. and do Couto, H. T. Z.: The Brazilian Soil Spectral Library (BSSL): A general view, application and challenges, Geoderma, 715 doi:10.1016/j.geoderma.2019.05.043, 2019.

Dickson, B. L. and Scott, K. M.: Interpretation of aerial gamma-ray surveys - adding the geochemical factors, AGSO J. Aust. Geol. Geophys., 17(2), 187-200, 1997.

Dobos, E.: The application of remote sensing and terrain modeling to soil characterization, Innov. Soil-Plant Syst. Sustain. Agric. Pract., 328-348, 2003.

Domsch, H. and Giebel, A.: Estimation of soil textural features from soil electrical conductivity recorded using the EM38, Precis. Agric., 5(4), 389-409, doi:10.1023/B:PRAG.0000040807.18932.80, 2004.

EMBRAPA: Documentos 132 Manual de Métodos de, Embrapa, (ISSN 1517-2627), 230, 2011.

EMBRAPA: Manual de metodos de analises., 2017.

Farzamian, M., Monteiro Santos, F. A. and Khalil, M. A.: Application of EM38 and ERT methods in estimation of saturated hydraulic conductivity in unsaturated soil, J. Appl. Geophys., 112, 175-189, doi:10.1016/j.jappgeo.2014.11.016, 2015.

Ferreira, R. G., da Silva, D. D., Elesbon, A. A. A., Fernandes-Filho, E. I., Veloso, G. V., de Souza Fraga, M. and Ferreira, L. B.: Machine learning models for streamflow regionalization in a tropical watershed, J. Environ. Manage., 280, 111713, 2021.

Filho, B.: Universidade de São Paulo Escola Superior de Agricultura “Luiz de Queiroz ” Comparação entre mapas de solos obtidos pelos métodos convencional e digital numa área complexa Osmar Bazaglia Filho Piracicaba, Master Diss. Soils Plant Nutr. 190 p, 190, 2012.

Fioriob, P. R.: Estimation of Soil Properties by Orbital and Laboratory Reflectance Means and its Relation with Soil Classification, Open Remote Sens. J., 2(1), 12-23, doi:10.2174/187541390100201012, 2013.

Fongaro, C. T., Demattê, J. A. M., Rizzo, R., Safanelli, J. L., Mendes, W. de S., Dotto, A. C., Vicente, L. E., Franceschini, 
https://doi.org/10.5194/gmd-2021-153

Preprint. Discussion started: 16 July 2021

(c) Author(s) 2021. CC BY 4.0 License.

735 M. H. D. and Ustin, S. L.: Improvement of clay and sand quantification based on a novel approach with a focus on multispectral satellite images, Remote Sens., 10(10), doi:10.3390/rs10101555, 2018.

Frihy, O. E., Lotfy, M. F. and Komar, P. D.: Spatial variations in heavy minerals and patterns of sediment sorting along the Nile Delta, Egypt, Sediment. Geol., 97(1-2), 33-41, 1995.

Geonics, E. M.: EM38 Ground Conductivity Meter Operating Manual, Geonics Ltd. Ontario Mississauga, ON, Canada, 32,

$740 \quad 2002$.

Greve, M. B. and Malone, B. P.: High-Resolution 3-D Mapping of Soil Texture in Denmark, , doi:10.2136/sssaj2012.0275, 2013.

Grimley, D. A., Arruda, N. K. and Bramstedt, M. W.: Using magnetic susceptibility to facilitate more rapid, reproducible and precise delineation of hydric soils in the midwestern USA, Catena, 58(2), 183-213, doi:10.1016/j.catena.2004.03.001,

7452004.

Harris, J. R. and Grunsky, E. C.: Computers \& Geosciences Predictive lithological mapping of Canada 's North using Random Forest classi fi cation applied to geophysical and geochemical data, Comput. Geosci., 80, 9-25, doi:10.1016/j.cageo.2015.03.013, 2015.

Heil, K. and Schmidhalter, U.: Theory and Guidelines for the Application of the Geophysical Sensor EM38, , 38, 2019.

750 Hendrickx, ; Kachanoski, R. .: Miscible Solute Transport -Solute Content and Concentration - Indirect Measurement of Solute Concentration: Electromagnetic Induction, in Methods of Soil Analysis, vol. Chapter 6., 2002.

Henrique, S., Silva, G., Silva, E. A., Poggere, G. C., Linares, A., Junior, P., Gabriele, M., Gonçalves, M., Roberto, L., Guilherme, G. and Curi, N.: Soils and Plant Nutrition Modeling and prediction of sulfuric acid digestion analyses data from PXRF spectrometry in tropical soils, Sci. Agric., 2018.

755 Heuvelink, G. B. M. and Webster, R.: Modelling soil variation: past, present, and future, Geoderma, 100(3-4), 269-301, 2001.

Honeyborne, I., McHugh, T. D., Kuittinen, I., Cichonska, A., Evangelopoulos, D., Ronacher, K., van Helden, P. D., Gillespie, S. H., Fernandez-Reyes, D., Walzl, G., Rousu, J., Butcher, P. D. and Waddell, S. J.: Profiling persistent tubercule bacilli from patient sputa during therapy predicts early drug efficacy, BMC Med., 14(1), 1-13, doi:10.1186/s12916-016-

760 0609-3, 2016.

Hothorn, T.: CRAN task view: Machine learning \& statistical learning, 2021.

Hounkpatin, O. K. L., Op, F., Hipt, D., Yaovi, A., Welp, G. and Amelung, W.: Catena Soil organic carbon stocks and their determining factors in the Dano catchment ( Southwest Burkina Faso ), Catena, 166(April), 298-309, doi:10.1016/j.catena.2018.04.013, 2018.

765 IUSS Working Group WRB: World reference base for soil resources 2014. International soil classification system for naming soils and creating legends for soil maps., 2015.

J. A. Quaggio, Raij, B.: Determination of pH in calcium chloride and total acidity., Chem. Anal. Fertil. Eval. Trop. Soils. Inst. Agronômico Campinas, Campinas, 181-188, 2001. 
https://doi.org/10.5194/gmd-2021-153

Preprint. Discussion started: 16 July 2021

(c) Author(s) 2021. CC BY 4.0 License.

Jafarzadeh, A. A., Pal, M., Servati, M., FazeliFard, M. H. and Ghorbani, M. A.: Comparative analysis of support vector machine and artificial neural network models for soil cation exchange capacity prediction, Int. J. Environ. Sci. Technol., 13(1), 87-96, doi:10.1007/s13762-015-0856-4, 2016.

Javadi, S. H., Munnaf, M. A. and Mouazen, A. M.: Fusion of Vis-NIR and XRF spectra for estimation of key soil attributes, Geoderma, 385, 114851, 2021.

Jenny, H.: Factors of soil formation: A system of quantitative pedology, Dover publication, New York., 1994.

Jiménez, C., Benavides, J., Ospina-Salazar, D. I., Zúñiga, O., Ochoa, O. and Mosquera, C.: Relationship between physical properties and the magnetic susceptibility in two soils of Valle del Cauca Relación entre propiedades físicas y la susceptibilidad magnética en dos suelos del Valle del Cauca, Cauca. Rev. Cienc. Agri, 34(341), 33-45, doi:10.22267/rcia.173402.70, 2017.

Johnston, M. A., Savage, M. J., Moolman, J. H. and du Plessis, H. M.: Evaluation of Calibration Methods for Interpreting

Soil Salinity from Electromagnetic Induction Measurements, Soil Sci. Soc. Am. J., 61(6), 1627-1633, doi:10.2136/sssaj1997.03615995006100060013x, 1997.

De Jong, E., Pennock, D. J. and Nestor, P. A.: Magnetic susceptibility of soils in different slope positions in Saskatchewan, Canada, Catena, 40(3), 291-305, doi:10.1016/S0341-8162(00)00080-1, 2000.

Jung, Y., Lee, J., Lee, M., Kang, N. and Lee, I.: Probabilistic analytical target cascading using kernel density estimation for accurate uncertainty propagation, Struct. Multidiscip. Optim., 1-19, 2020.

Kämpf, N. and Curi, N.: Óxidos de ferro: indicadores de ambientes pedogênicos e geoquímicos, Tópicos em ciência do solo, 1, 107-138, 2000.

Kuhn, M. and Johnson, K.: Applied predictive modeling, Springer., 2013.

Kuhn, M., Wing, J., Weston, S., Williams, A., Keefer, C., Engelhardt, A., Cooper, T., Mayer, Z., Kenkel, B. and Team, R.

C.: Package 'caret,' R J., 2020.

Lacoste, M., Lemercier, B. and Walter, C.: Regional mapping of soil parent material by machine learning based on point data, Geomorphology, 133(1-2), 90-99, doi:10.1016/j.geomorph.2011.06.026, 2011.

Lagacherie, P., Arrouays, D., Bourennane, H., Gomez, C., Martin, M. and Saby, N. P. A.: How far can the uncertainty on a Digital Soil Map be known?: A numerical experiment using pseudo values of clay content obtained from Vis-SWIR 795 hyperspectral imagery, Geoderma, 337, 1320-1328, 2019.

Leng, X., Qian, X., Yang, M., Wang, C., Li, H. and Wang, J.: Leaf magnetic properties as a method for predicting heavy metal concentrations in PM 2.5 using support vector machine : A case study in Nanjing, China, Environ. Pollut., 242, 922930, doi:10.1016/j.envpol.2018.07.007, 2018.

Lesch, S. M., Rhoades, J. D., Lund, L. J. and Corwin, D. L.: Mapping soil salinity using calibrated electromagnetic 800 measurements, Soil Sci. Soc. Am. J., 56(2), 540-548, 1992.

Levi, M. R. and Rasmussen, C.: Covariate selection with iterative principal component analysis for predicting physical soil properties, Geoderma, 219, 46-57, 2014. 
https://doi.org/10.5194/gmd-2021-153

Preprint. Discussion started: 16 July 2021

(c) Author(s) 2021. CC BY 4.0 License.

Li, H., Wang, J., Wang, Q., Tian, C., Qian, X. and Leng, X.: Magnetic Properties as a Proxy for Predicting Fine-ParticleBound Heavy Metals in a Support Vector Machine Approach, Environ. Sci. Technol., 51(12), 6927-6935, doi:10.1021/acs.est.7b00729, 2017.

Liao, K., Xu, S., Wu, J., Zhu, Q. and An, L.: Using support vector machines to predict cation exchange capacity of different soil horizons in Qingdao City, China, J. Plant Nutr. Soil Sci., 177(5), 775-782, 2014.

Ließ, M., Glaser, B. and Huwe, B.: Uncertainty in the spatial prediction of soil texture: Comparison of regression tree and Random Forest models, Geoderma, 170, 70-79, doi:https://doi.org/10.1016/j.geoderma.2011.10.010, 2012.

810 Lim, C.H., Jackson, M. L.: Dissolution for total elemental analysis, in Methods of Soil Analysis. Part 2: Chemical and Microbiological Properties., edited by Madison, pp. 1-12, American Society of Agronomy., 1986.

Loiseau, T., Richer-de-forges, A. C., Martelet, G., Bialkowski, A., Nehlig, P. and Arrouays, D.: Geoderma Regional Could airborne gamma-spectrometric data replace lithological maps as co-variates for digital soil mapping of topsoil particle-size distribution? A case study in Western France, Geoderma Reg., 22, e00295, doi:10.1016/j.geodrs.2020.e00295, 2020.

815 Malone, B. P., McBratney, A. B., Minasny, B. and Laslett, G. M.: Mapping continuous depth functions of soil carbon storage and available water capacity, Geoderma, 154(1-2), 138-152, doi:10.1016/j.geoderma.2009.10.007, 2009.

McFadden, M. and Scott, W. R.: Broadband soil susceptibility measurements for EMI applications, J. Appl. Geophys., 90, 119-125, doi:10.1016/j.jappgeo.2013.01.009, 2013.

Mcneill, J. D.: Rapid, accurate mapping of soil salinity by electromagnetic ground conductivity meters, , (30), 2-3, 1992.

McNeill, J. D.: Geonics EM38 ground conductivity meter, Tech. Note TN-21. Geonics Ltd., Mississauga, Ontario, Canada, 1986.

Mello, D., Demattê, J. A. M., Silvero, N. E. Q., Di Raimo, L. A. D. L., Poppiel, R. R., Mello, F. A. O., Souza, A. B., Safanelli, J. L., Resende, M. E. B. and Rizzo, R.: Soil magnetic susceptibility and its relationship with naturally occurring processes and soil attributes in pedosphere, in a tropical environment, Geoderma, 372(March), 114364, doi:10.1016/j.geoderma.2020.114364, 2020.

Mello, D., Alexandre Melo Demattê, J., Alcantara de Oliveira Mello, F., Roberto Poppiel, R., ElizabetQuiñonez Silvero, N., Lucas Safanelli, J., Barros e Souza, A., Augusto Di Loreto Di Raimo, L., Rizzo, R., Eduarda Bispo Resende, M. and Ernesto Gonçalves Reynaud Schaefer, C.: Applied gamma-ray spectrometry for evaluating tropical soil processes and attributes, Geoderma, 381, doi:10.1016/j.geoderma.2020.114736, 2021.

830 Minty, B. R. S.: A Review of Airborne Gamma-Ray Spectrometric Data-Processing Techniques, Aust. Gov. Publ. Serv., 1988.

Montanarella, L., Pennock, D. J., McKenzie, N. J., Badraoui, M., Chude, V., Baptista, I., Mamo, T., Yemefack, M., Singh Aulakh, M. and Yagi, K.: World's soils are under threat, Soil, 2(2), 1263-1272, 2015.

Mullins, C. E.: Magnetic susceptibility of the soil and its significance in soil science-a review, J. soil Sci., 28(2), 223-246, 8351977.

Nanni, M. R. and Demattê, J. A. M.: Spectral Reflectance Methodology in Comparison to Traditional Soil Analysis, Soil Sci. 
https://doi.org/10.5194/gmd-2021-153

Preprint. Discussion started: 16 July 2021

(c) Author(s) 2021. CC BY 4.0 License.

(c) (i)

Soc. Am. J., 70(2), 393-407, doi:10.2136/sssaj2003.0285, 2006.

Narjary, B., Meena, M. D., Kumar, S., Kamra, S. K., Sharma, D. K. and Triantafilis, J.: Digital mapping of soil salinity at various depths using an EM38, Soil Use Manag., 35(2), 232-244, doi:10.1111/sum.12468, 2019.

840 Nawar, S., Buddenbaum, H., Hill, J., Kozak, J. and Mouazen, A. M.: Estimating the soil clay content and organic matter by means of different calibration methods of vis-NIR diffuse reflectance spectroscopy, Soil Tillage Res., 155, 510-522, doi:10.1016/j.still.2015.07.021, 2016.

Neogi, S. and Dauwels, J.: Factored Latent-Dynamic Conditional Random Fields for Single and Multi-label Sequence Modeling, arXiv Prepr. arXiv1911.03667, 2019.

845 O’Rourke, S. M., Stockmann, U., Holden, N. M., McBratney, A. B. and Minasny, B.: An assessment of model averaging to improve predictive power of portable vis-NIR and XRF for the determination of agronomic soil properties, Geoderma, 279, 31-44, doi:10.1016/j.geoderma.2016.05.005, 2016.

Pansu, M., Gautheyrou, J.: Handbook of Soil Analysis - Mineralogical, Organic and Inorganic Methods., Springer, Netherlands., 2006.

850 Perlich, C.: Learning Curves in Machine Learning., 2010.

Pozza, L. E. and Field, D. J.: The science of soil Security and food security, Soil Secur., 1, 100002, 2020.

Priori, S., Fantappiè, M., Bianconi, N., Ferrigno, G., Pellegrini, S. and Costantini, E. A. C.: Field-Scale Mapping of Soil Carbon Stock with Limited Sampling by Coupling Gamma-Ray and Vis-NIR Spectroscopy, Soil Sci. Soc. Am. J., 80(4), 954-964, doi:10.2136/sssaj2016.01.0018, 2016.

855 Reinhardt, N. and Herrmann, L.: Gamma-ray spectrometry as versatile tool in soil science: A critical review, J. Plant Nutr. Soil Sci., 182(1), 9-27, doi:10.1002/jpln.201700447, 2019.

Rhoades, J. D., Chanduvi, F. and Lesch, S. M.: Soil salinity assessment: Methods and interpretation of electrical conductivity measurements, Food \& Agriculture Org., 1999.

Richards, L. A.: Diagnosis and improvement of saline and alkali soils, LWW., 1954.

860 Rochette, P., Jackson, M. and Aubourg, C.: Rock magnetism andn the interpretation of magnetic susceptibility, Rev. Geophys., 30(3), 209-226, 1992.

Rytky, S. J. O., Tiulpin, A., Frondelius, T., Finnilä, M. A. J., Karhula, S. S., Leino, J., Pritzker, K. P. H., Valkealahti, M., Lehenkari, P., Joukainen, A., Kröger, H., Nieminen, H. J. and Saarakkala, S.: Automating three-dimensional osteoarthritis histopathological grading of human osteochondral tissue using machine learning on contrast-enhanced micro-computed tomography, Osteoarthr. Cartil., 28(8), 1133-1144, doi:10.1016/j.joca.2020.05.002, 2020.

Sarmast, M., Farpoor, M. H. and Esfandiarpour Boroujeni, I.: Magnetic susceptibility of soils along a lithotoposequence in southeast Iran, Catena, 156(March), 252-262, doi:10.1016/j.catena.2017.04.019, 2017.

Schaetzl, J Randall and Anderson, S.: Soil Genesis and Geomorphology, Cambridge University Press, New York., 2005.

Schuler, U., Erbe, P., Zarei, M., Rangubpit, W., Surinkum, A., Stahr, K. and Herrmann, L.: A gamma-ray spectrometry approach to field separation of illuviation-type WRB reference soil groups in northern Thailand, J. Plant Nutr. Soil Sci., 
https://doi.org/10.5194/gmd-2021-153

Preprint. Discussion started: 16 July 2021

(c) Author(s) 2021. CC BY 4.0 License.

174(4), 536-544, doi:10.1002/jpln.200800323, 2011.

Schwertmann, U. and Taylor, R. M.: Iron oxides, Miner. soil Environ., 1, 379-438, 1989.

Shenggao, L.: Lithological factors affecting magnetic susceptibility of subtropical soils, Zhejiang Province, China, Catena, 40(4), 359-373, doi:10.1016/S0341-8162(00)00092-8, 2000.

875 Silva, C. S., Silva-Filho, F. C., Santos, A. D., COSciOnE, A. R., Vitti, A., BOARETTO, A., Coelho, J. A. P., Bvan, R., Silva, C. A. and Abreu, C. H.: Manual de análises químicas de solos, plantas e fertilizantes., 2009.

Silva, E. B.: A Regional Legacy Soil Dataset for Prediction of Sand and Clay Content with Vis-Nir-Swir, in Southern Brazil, Rev. Bras. Cienc. do Solo, 1-20, 2019.

Siqueira, D. S., Marques, J., Matias, S. S. R., Barrón, V., Torrent, J., Baffa, O. and Oliveira, L. C.: Correlation of properties 880 of Brazilian Haplustalfs with magnetic susceptibility measurements, Soil Use Manag., 26(4), 425-431, doi:10.1111/j.14752743.2010.00294.x, 2010.

Solutions, R.: Spectrum stabilization and calibration for the RSI RS-125 and RS-230 handheld spectrometers, 2009.

Sousa, I., Costa, L., Cavalcanti, I., Oliveira, C. De, Tavares, F. M., José, H., Polo, D. O., Sousa, I., Costa, L., Cavalcanti, I. and Oliveira, C. De: Uranium anomalies detection through Random Forest regression Uranium anomalies detection through

885 Random Forest regression, , doi:10.1080/08123985.2020.1725387, 2020.

de Souza Bahia, A. S. R., Marques, J., La Scala, N., Pellegrino Cerri, C. E. and Camargo, L. A.: Prediction and mapping of soil attributes using diffuse reflectance spectroscopy and magnetic susceptibility, Soil Sci. Soc. Am. J., 81(6), 1450-1462, 2017.

Targulian, V.O.; Arnold, R.W.; Miller, B. A. . B.: Encyclopedia of Ecology, 2nd ed., The Netherlands; Elsevier: Amsterdam,

890 Volume 4, 162-168., 2019.

Taylor, M. J., Smettem, K., Pracilio, G. and Verboom, W.: Relationships between soil properties and high-resolution radiometrics, central eastern Wheatbelt, Western Australia, Explor. Geophys., 33(2), 95-102, doi:10.1071/EG02095, 2002a.

Taylor, M. J., Smettem, K., Pracilio, G. and Verboom, W.: Relationships between soil properties and high-resolution radiometrics, central eastern Wheatbelt, Western Australia, Explor. Geophys., 33(2), 95-102 [online] Available from:

895 https://doi.org/10.1071/EG02095, 2002b.

Terra, F. S., Demattê, J. A. M. and Viscarra Rossel, R. A.: Proximal spectral sensing in pedological assessments: vis-NIR spectra for soil classification based on weathering and pedogenesis, Geoderma, 318(January), 123-136, doi:10.1016/j.geoderma.2017.10.053, 2018a.

Terra, F. S., Demattê, J. A. M. and Viscarra Rossel, R. A.: Proximal spectral sensing in pedological assessments: vis-NIR

900 spectra for soil classification based on weathering and pedogenesis, Geoderma, 318(October 2017), 123-136, doi:10.1016/j.geoderma.2017.10.053, 2018b.

Triantafilis, J., Lesch, S. M., La Lau, K. and Buchanan, S. M.: Field level digital soil mapping of cation exchange capacity using electromagnetic induction and a hierarchical spatial regression model, Aust. J. Soil Res., 47(7), 651-663, doi:10.1071/SR08240, 2009. 
https://doi.org/10.5194/gmd-2021-153

Preprint. Discussion started: 16 July 2021

(c) Author(s) 2021. CC BY 4.0 License.

(c) (i)

905 Valaee, M., Ayoubi, S., Khormali, F., Lu, S. G. and Karimzadeh, H. R.: Using magnetic susceptibility to discriminate between soil moisture regimes in selected loess and loess-like soils in northern Iran, J. Appl. Geophys., 127, 23-30, doi:10.1016/j.jappgeo.2016.02.006, 2016.

Vašát, R., Kode, R., Klement, A. and Brodský, L.: Combining re fl ectance spectroscopy and the digital elevation model for soil oxidizable carbon estimation, , 303(May), 133-142, doi:10.1016/j.geoderma.2017.05.018, 2017.

910 Viana, J. H. M., Couceiro, P. R. C., Pereira, M. C., Fabris, J. D., Fernandes Filho, E. I., Schaefer, C., Rechenberg, H. R., Abrahão, W. A. P. and Mantovani, E. C.: Occurrence of magnetite in the sand fraction of an Oxisol in the Brazilian savanna ecosystem, developed from a magnetite-free lithology, Soil Res., 44(1), 71-83, 2006.

Viscarra Rossel, R. A., Webster, R. and Kidd, D.: Mapping gamma radiation and its uncertainty from weathering products in a Tasmanian landscape with a proximal sensor and random forest kriging, Earth Surf. Process. Landforms, 39(6), 735-748, 915 doi:10.1002/esp.3476, 2014.

Wilford, J. and Minty, B.: Chapter 16 The Use of Airborne Gamma-ray Imagery for Mapping Soils and Understanding Landscape Processes, Dev. Soil Sci., 31(C), doi:10.1016/S0166-2481(06)31016-1, 2006.

Wilford, J. and Thomas, M.: Modelling soil-regolith thickness in complex weathered landscapes of the central Mt Lofty Ranges, South Australia, 2012.

920 Wilford, P. N., Bierwirth, J. R. and Craig, M. A.: Application of airborne gamma-ray spectrometry in soiVregolith mapping and Applied Geomorphology, , 17(2), 1997.

Wong, M. T. F. and Harper, R. J.: Use of on-ground gamma-ray spectrometry to measure plant-available potassium and other topsoil attributes, Aust. J. Soil Res., 37(2), 267-277, doi:10.1071/S98038, 1999.

Xu, D., Zhao, R., Li, S., Chen, S., Jiang, Q., Zhou, L. and Shi, Z.: Multi-sensor fusion for the determination of several soil 925 properties in the Yangtze River Delta, China, Eur. J. Soil Sci., 70(1), 162-173, 2019.

Zare, E., Li, N., Khongnawang, T. and Farzamian, M.: Identifying Potential Leakage Zones in an Irrigation Supply Channel by Mapping Soil Properties Using Electromagnetic Induction, Inversion Modelling and a Support Vector Machine, 2020.

Zhang, Y. and Hartemink, A. E.: Data fusion of vis - NIR and PXRF spectra to predict soil physical and chemical properties, Eur. J. Soil Sci., (May 2019), 316-333, doi:10.1111/ejss.12875, 2020. 